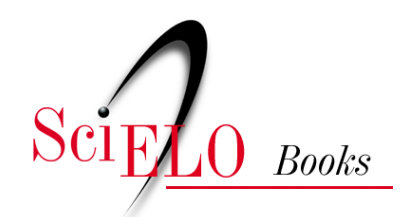

Editora da UESC

\title{
Planejamento em Enfermagem \\ aplicação do processo de enfermagem na prática administrativa
}

\author{
Ricardo Matos Santana \\ Ângela Tamiko Sato Tahara
}

SANTANA, R.M., and TAHARA, Â.T.S. Planejamento em Enfermagem: aplicação do processo de enfermagem na prática administrativa [online]. Ilhéus: Editus, 2008, 111 p. ISBN: 978-85-7455-5294. https://doi.org/10.7476/9788574555294.

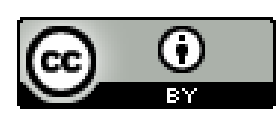

All the contents of this work, except where otherwise noted, is licensed under a Creative Commons Attribution 4.0 International license.

Todo o conteúdo deste trabalho, exceto quando houver ressalva, é publicado sob a licença Creative Commons Atribição 4.0.

Todo el contenido de esta obra, excepto donde se indique lo contrario, está bajo licencia de la licencia Creative Commons Reconocimento 4.0. 


\section{Planejamento em Enfermagem \\ Aplicação do Processo de Enfermagem na prática administrativa}




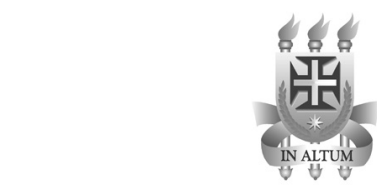

\section{Universidade Estadual de Santa Cruz}

GOVERNO DO ESTADO DA BAHIA

Jaques WaGNer - Governador

SECRETARIA DE EDUCAÇÃO

Adeum Hilário Sauer - Secretário

UNIVERSIDADE ESTADUAL DE SANTA CRUZ

Antonio Joaquim Bastos da Silva - Reitor

Adélia Maria Carvalho de Melo Pinheiro - Vice-Reitora

\section{DIRETORA DA EDITUS}

Maria Luiza Nora

Conselho Editorial:

Maria Luiza Nora - Presidente

Adélia Maria Carvalho de Melo Pinheiro

Antônio Roberto da Paixão Ribeiro

Fernando Rios do Nascimento

Jaênes Miranda Alves

Jorge Octavio Alves Moreno

Lino Arnulfo Vieira Cintra

Lourival Pereira Junior

Maria Laura Oliveira Gomes

Maria Neusa de Oliveira

Marileide Santos Oliveira

Ricardo Matos Santana

Ronan Xavier Corrêa 


\author{
Ricardo Matos Santana \\ Ângela Tamiko Sato Tahara
}

\title{
Planejamento \\ em Enfermagem \\ Aplicação do Processo de Enfermagem na prática administrativa
}

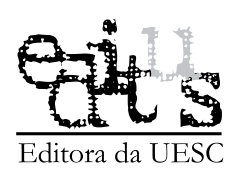

Ilhéus - Bahia 


\title{
(C)2008 by Ricardo Matos Santana \\ Ângela Tamiko Sato TaHara
}

Direitos desta edição reservados à

EDITUS - EDITORA DA UESC

Universidade Estadual de Santa Cruz

Rodovia Ilhéus/Itabuna, km 16 - 45662-000 Ilhéus, Bahia, Brasil

Tel.: (73) 3680-5028 - Fax: (73) 3689-1126

http://www.uesc.br/editora e-mail: editus@uesc.br

\author{
PROJETO GRÁFICO \\ Alencar Júnior \\ DIAGRAMAÇÃO E CAPA \\ Álvaro Coelho
}

REVISÃO

Maria Luiza Nora

Aline Nascimento

Dados Internacionais de Catalogação na Publicação (CIP)

\author{
S232 Santana, Ricardo Matos. \\ Planejamento em Enfermagem : aplicação do Processo \\ de Enfermagem na prática administrativa / Ricardo Matos \\ Santana, Ângela Tamiko Sato Tahara. - Ilhéus : Editus, \\ 2008. \\ $111 \mathrm{p}$. \\ Bibliografia.
}

ISBN: 978-85-7455-153-1

1.Serviços de Enfermagem - Administração. 2. Enfermagem prática. 3. Saúde - Planejamento. I. Tahara, Ângela Tamiko Sato. II. Título.

$$
\text { CDD - } 610.7306
$$

Ficha catalográfica: Elisabete Passos dos Santos - CRB5/533 


\section{SUMÁRIO}

Introdução

\section{PARTE I \\ CONCEPÇÓES TEÓRICAS PARA O \\ PLANEJAMENTO EM ENFERMAGEM}

1 O planejamento como função administrativa................11

2 O planejamento como prática histórica........................15

3 A inserção da estratégia no planejamento.................... 18

4 Planejamento normativo e estratégico .........................23

5 Planejamento em saúde na América Latina ...................26

5.1 A CEPAL e a introdução da idéia do planejamento na América Latina....................................................26

5.2 A consolidação do enfoque estratégico (tipos de planejamento estratégico) .............................................30

6 O Planejamento Estratégico Situacional.......................33

A) O Planejamento de Projetos Orientado por Objetivos - ZOPP 38

B) O Método Altadir de Planificação Popular MAPP ............................................................40

6.1 Planejamento como método de governo ...............41

6.2 A metodologia do Planejamento Estratégico

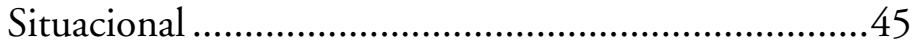

6.2.1 Momento Explicativo ..............................46

6.2.2 Momento Normativo ................................47

6.2.3 Momento Estratégico ...............................48

6.2.4 Momento Tático-operacional .....................49

7 Planejamento Estratégico no gerenciamento de Enfermagem ............................................................. 50 


\section{PARTE II \\ O PROCESSO DE PLANEJAMENTO EM ENFERMAGEM}

8 Algumas consideraçóes quanto ao Processo de Enfermagem

9 Bases conceituais e metodológicas .................................66

10 Momento de Investigação..........................................70

10.1 Formulação de Problemas .................................72

10.1.1 Critérios para considerar um problema ....73

10.1.2 Regras para formular um problema...........73

10.2 Priorização de problemas.....................................74

10.2.1 Problemas da Unidade de Saúde ................75

10.2.2 Problemas do estado de saúde da

população.......................................................77

10.3 Explicação dos Problemas...................................79

11 Momento de diagnóstico.............................................87

12 Momento de planejamento ....................................... 92

12.1 Priorização das intervenções ..............................92

12.2 Definições dos objetivos..................................93

12.3 Prescrição de intervenções .................................96

12.4 Análise de viabilidade......................................98

12.5 Plano de ação ................................................99

13 Momento de implementação ..................................... 102

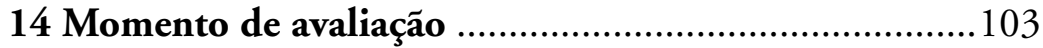

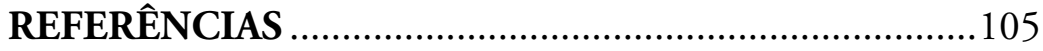




\section{Introdução}

A valorização das funções administrativas do enfermeiro, além do cuidado direto com o usuário, é considerada de importância para a construção de conhecimento específico da Enfermagem, bem como para o enfrentamento dos desafios propostos pelo sistema de saúde, buscando a autonomia dos sujeitos que operam o trabalho em saúde, com vistas ao gerenciamento do cuidado (FRACOLLI; EGRY, 2001). Spagnol (2005) acrescenta que, nos diversos serviços de saúde, a gerência de Enfermagem, além de organizar o processo de trabalho da Enfermagem, tem adquirido importância, até de forma essencial, na articulação entre os vários profissionais da equipe, buscando consolidar as açôes a serem realizadas junto aos usuários do sistema de saúde.

O processo administrativo, por sua vez, envolve, na sua forma clássica, a execução seqüencial das funções administrativas, como planejar, organizar, dirigir e controlar. A função planejar é considerada a primeira e uma das mais importantes funçōes administrativas, em função de servir de base para as demais funçóes administrativas (CIAMPONE, 1991). O ato de planejar está incorporado em todas as funçóes do enfermeiro, servindo tanto para sistematizar o trabalho, como para prever mudanças e adequar os recursos visando propiciar o alcance dos objetivos propostos. Para o planejamento do cuidado, foram propostos vários métodos, geralmente denominados de Processo de Enfermagem (CASTILHO; GAIDZINSKI, 1991).

$\mathrm{Na}$ saúde, são amplamente utilizadas as vertentes de planejamento estratégico propostas pela Escola de Medellín (Enfoque Estratégico da Programação em Saúde), por Mario Testa (Pensamento Estratégico) e, principalmente, por Carlos Matus (Planejamento Estratégico Situacional). Essas vertentes se contrapōem ao modelo de planejamento do CENDES-OPS (Centro Nacional de Desenvolvi- 
mento - Organização Pan-americana de Saúde, localizada na Universidade Central da Venezuela), combatido e considerado normativo. Embora se perceba uma forte influência da técnica CENDES/OPS, como forma de racionalizar os recursos e o processo de trabalho, este é caracterizado pela valorização excessiva da produtividade e pela inércia em buscar novos modelos de trabalho.

O presente texto tem como objetivo apresentar uma forma de sistematizar o processo de Planejamento em Enfermagem, através da combinação dos métodos de planejamento existentes nas ciências da Saúde empregadas na América Latina com elementos da ciência da Administração (elementos de métodos de análise e melhoria de processos desenvolvidos em programas de gestão da qualidade total) e organizados segundo a estrutura metodológica do Processo de Enfermagem, dentro dos cinco momentos distintos e interdependentes, identificados como investigação, diagnóstico, planejamento, implementação e avaliação.

Não é retratado o PES como proposto por Carlos Matus, mas um pinçamento de elementos essenciais da base conceitual proposta e adaptada à estrutura do método de planejamento próprio da Enfermagem - o Processo de Enfermagem, potencializando o papel do enfermeiro enquanto gerente do processo de Planejamento em Enfermagem, e até no setor de Saúde, promovendo autonomia dos sujeitos/atores (trabalhador e usuário) e mudança das práticas de Enfermagem e de Saúde.

Partindo do pressuposto de que não existe "a teoria" ou "o método" de planejamento e que o melhor método é aquele que melhor ajudar numa determinada situação, torna-se pouco provável que, na prática, alguém siga a risca um determinado método. É mais provável que no encadeamento do trabalho os profissionais vão incorporando diversos instrumentos de trabalho retirados de muitas partes (Tancredi et al., 1998). E, como o próprio Matus aconselha, é necessário combinar métodos distintos, conforme o nível de hierarquia e de complexidades dos problemas. 


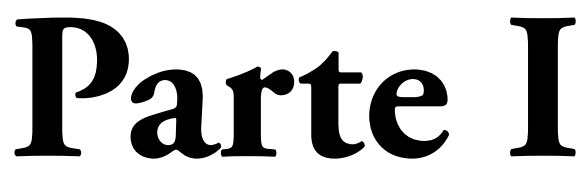

Concepções teóricas para

o Planejamento em

Enfermagem 


\section{1 \\ O planejamento como função administrativa}

Dentre os saberes de várias ciências que foram incorporados aos da Enfermagem, encontram-se os da ciência da administração, a qual, segundo Arndt e Huckabay (1983), é formada por uma parte principal derivada da teoria primária ou clássica, proporcionando uma estrutura e terminologia conceituais, que foi evoluindo até o período moderno, quando procura dar maior enfoque às abordagens sistêmica e contingencial. Nestas abordagens, considera-se organização social e técnica como um todo do universo e como um sistema complexo de elementos em interação mútua.

Para Lins et al. (2000), a teoria sistêmica busca o equilíbrio entre a organização e o ambiente, e considera a teoria contingencial como uma evolução da teoria sistêmica, procurando explicar que não há nada de absoluto nos princípios da organização, e que os aspectos universais e normativos devem ser substituídos pelo critério de ajuste entre organização, ambiente e tecnologia.

A evolução da ciência da administração vem contribuindo para o entendimento da prática da Enfermagem através da reflexão sobre essa prática à luz das teorias administrativas, uma vez que estas coexistem em diferentes graus na administração em Enfermagem (KURCGANT, 1991). A evolução das teorias administrativas vem contribuindo para o avanço tecnológico na área gerencial nas últimas décadas. 
Kwasnika (1989) considera que as pesquisas demonstram que não há uma forma única de estruturar uma organização, como se pensava anteriormente.

Arndt \& Huckabay (1983) afirmam que a administração do serviço de Enfermagem é abrangente e multidimensional, e que este administrador deve compreender a necessidade de aproveitar e utilizar os princípios das várias teorias da administração.

Segundo Chiavenato (2000), as organizaçōes, por seu tamanho e pela sua complexidade, precisam ser administradas, e essa administração requer pessoas estratificadas em diversos níveis hierárquicos e diferentes funções. A administração envolve as funções de planejamento, organização, direção e controle de todas as atividades diferenciadas pela divisão de trabalho que ocorrem dentro de uma organização (Figuras 1 e 2).

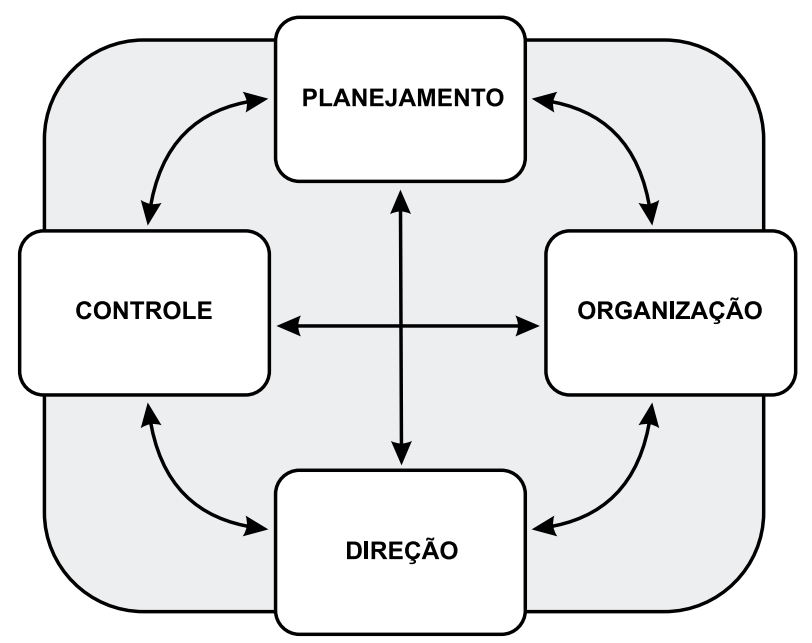

Figura 1 - As Funções Administrativas.

Fonte: Adaptado de Chiavenato (1999, p. 14).

Dentre estas funções, o planejamento pode ser considerado uma "chave mestra", que, quando adequada, encaixa-se perfeitamente às organizaçôes e aos organizadores, os quais necessitam 
enfrentar os desafios ambientais e organizacionais, complexos e dinâmicos, que sofrem constantes mudanças tecnológicas, políticas, sociais, econômicas e de relações humanas, como também, os problemas cotidianos que são de suma importância.

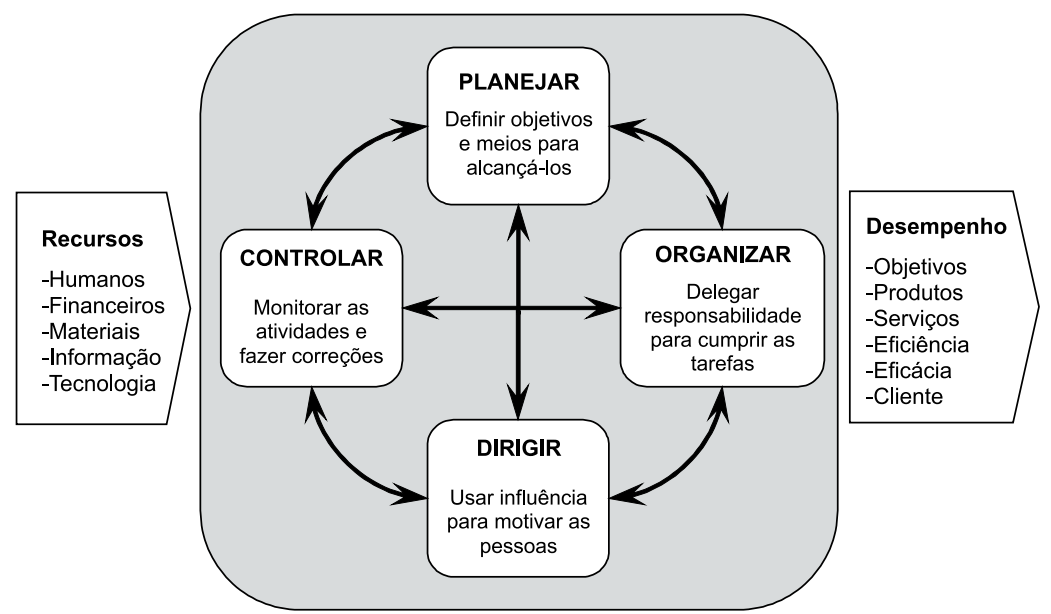

Figura 2 - O Processo Administrativo.

Fonte: Adaptado de Chiavenato (1999, p. 16).

Para os estudiosos da administração, o planejamento costuma figurar como a primeira das funções administrativas, sendo considerada uma das mais importantes, uma vez que serve de base para o desenvolvimento das demais.

Segundo Chiavenato (1985), o planejamento é um modelo teórico para uma ação futura; é a função administrativa que determina antecipadamente o que se deve fazer e quais os objetivos que se deseja atingir, tendendo a focalizar a atenção dos atores sociais nos objetivos, que, através de constantes revisões poderão ser alcançados de uma forma mais célere.

Kast e Rosenzweig (1980) definem planejamento como sendo a função-chave da administração, porque fornece aos indivíduos e às organizaçôes os meios de que necessitam para enfrentar 
esses ambientes dinâmicos, complexos e em constantes transformaçôes. Por outro lado, o planejamento subsidia os atores sociais com suporte para a tomada de decisões, possibilita o sucesso das operações, contribui para facilitar a supervisão e avaliação das atividades de Enfermagem, além de prevenir a ocorrência de falta de recursos, conseqüentemente, evita improvisaçôes das atividades de Enfermagem. 


\section{2 \\ O planejamento como prática histórica}

O pensamento cartesiano, ancorado na racionalização exagerada, e consolidando os princípios de separação e de redução, influenciou muito a forma de gerir organizações, e o Estado, principalmente a partir da revolução industrial, instaura a exploração humana e ecológica até as últimas conseqüências (DE MASI, 2000).

Esse autor afirma que, até hoje, estamos impregnados desta concepção racionalista que foi absorvida totalmente pelo poder dominante e assimilada principalmente pelas fábricas (motores da expansão capitalista), que expulsam tudo aquilo que não é racional: a dimensão emotiva, estética e, em parte, também, a ética.

Além disso, sob a denominação de planejamento, estão histórias, conhecimentos, propostas e experiências distintas. Alguns estudiosos acreditam que o planejamento tem potencialidade para enfrentar os problemas das intervenções do homem no mundo. Outros afirmam ser o planejamento um instrumento a serviço da dominação social, como mecanismo biológico e instrumento de exclusão, ou controle político (MERHY, 1995).

Segundo o mesmo autor, o planejamento, como instrumento/atividade do processo de gestão das organizações, tem sido tema do conjunto da Teoria Geral da Administração, em suas diversas correntes e/ou configurações metodológicas. Somando-se aos saberes e práticas articulados dentro de uma perspectiva 
sistêmico-funcional, de modo instrumental e em termos de eficácia operacional, tem interferido positivamente na produção de riquezas e alterado os seus mecanismos de usufruto.

Extrapolando o campo da Teoria Geral da Administração e avançando para o da política, o planejamento foi abordado, por um lado, no interior das experiências das sociedades que pretenderam - dentro de marcos teóricos e ideológicos específicos - construir o socialismo a partir da ação interventora do Estado Interventor; e, por um outro, foi abordado em

[...] projetos que vêem no planejamento o segredo para a construção de um método de ação, procurando instrumentalizar plenamente a política, como tem pretendido Carlos Matus com o Planejamento Estratégico Situacional, descontando o método de ação da situação real dos sujeitos e histórico-sociais, transformando o próprio método em sujeito (MERHY, 1995, p.122).

A função de planejar está inserida na prática administrativa desde o tempo de Taylor (1856-1917), quando foram definidos os princípios que sugerem que os administradores devem desenvolver um método científico para cada elemento do trabalho de um homem a fim de substituir as velhas regras, ou seja, planejar o trabalho do operário, para que sua execução seja realizada de maneira eficaz e eficiente, visando ao aumento da produção (CHIAVENATO, 2000).

Para este autor, o taylorismo e o fordismo mudaram a forma de produção capitalista, de fragmentada para a produção em série, com a correia de transmissão em cadeia, com um planejamento sistemático do processo de trabalho para adaptação do homem a esse processo, traduzindo, ao mesmo tempo a exigência capitalista de produtividade e de controle global de unidades.

Esse modelo (Taylorista e Fordista), segundo Chiavenato (2000), é caracterizado pela preocupação em aumentar a eficiência da empresa através da forma de disposição dos órgãos 
componentes da organização (departamentos) e suas interrelaçōes estruturais (setores). Daí a ênfase na anatomia (estrutura) e na fisiologia (funcionamento). Este modelo é também conhecido como Modelo Anatomista e Fisiologista da Organização.

Taylor e Fayol consolidam a separação entre decisão e execução, entre o poder de ordenar e a prática do executar sob a égide da organização científica do trabalho (CHIAVENATO, 2000).

O papel e a importância da função de planejar não sofreram mudanças, porém, o método, o como planejar, mudou, visando ao futuro, e à necessidade de acompanhar a era da transformação tecnológica e da valorização do ser humano. 


\section{3 \\ A inserção da estratégia no planejamento}

Para autores como Barelli e Troyano (1991), e Matus (1993), o planejamento que visa apenas à manutenção do avanço do capitalismo, interessado somente no crescimento e desenvolvimento da produção industrial e no comércio é considerado como planejamento tradicional. Explicando-se pela lógica das normas, torna-se inviável na medida em que sofre as mudanças sociais, políticas e econômicas devido à falta de previsibilidade para o enfrentamento da realidade. Muitas vezes, os valores e as relevâncias anteriores tornam-se motivos impeditivos, irrecuperáveis para o progresso institucional.

Nesse sentido, diante do reconhecimento de inviabilidade e limitação que porta o planejamento tradicional, em alguns sentidos, faz-se necessária a criação de novos métodos de planejamento que ofereçam meios estratégicos para enfrentar a celeridade da evolução da realidade.

No que se refere à estratégia, Motta (1998) aponta que a palavra 'estratégia', nos últimos vinte anos, é a que mais tem sido associada à administração, servindo, hoje, não só para qualificar a própria administração - administração estratégica, como também todas as funções administrativas - decisão estratégica, escolha estratégica, postura estratégica, delineamento estratégico, organização estratégica, participação estratégica, planejamento estratégico, a avaliação estratégica, entre outras. 
O referido autor ressalta que essa palavra qualificativa permanece em detrimento das outras que surgem nas perspectivas de desenvolvimento da teoria e na prática gerencial, afirmando que:

Em outras instâncias, a administração foi ganhando novos adjetivos à medida que se queria melhor qualificá-la, ainda que genericamente, ou mesmo a qualquer uma de suas funçôes. Assim, surgiram termos e conceitos como mecanicista, sistêmica, contingencial, participativa etc. No entanto, quando se chegou à qualificação estratégica, a idéia permaneceu e seu uso foi ampliado (MOTTA, 1998, p. 78).

A palavra estratégia é de origem grega, aproximadamente 500 anos a. C., e servia para designar a função administrativa do generalato. Isso explica por que o conceito de estratégia esteve sempre associado à visão militar. Clausewitz, citado por Motta (1998), desenvolve a idéia de estratégia em seu sentido atual, ou seja, na amplitude e na interdependência da guerra com dimensões sociais, políticas e econômicas, adquirindo, contemporaneamente, um sentido mais amplo do que a própria guerra, significando planos e alternativas de segurança ou atitudes de luta que poderão ou não incluir a guerra (MOTTA, 1998).

O mesmo autor cita que, na perspectiva militar, a estratégia era vista essencialmente como uma arte, isto é, a arte do generalato. A administração procurou dar uma conotação científica ao termo estratégia, associando-o à formulação de diretrizes e ao planejamento, principalmente após a segunda metade deste século.

Motta, ao tecer comentários acerca da conquista da visão estratégica na gerência, afirma que:

A necessidade de estudar e aplicar a noção de estratégia em administração passou a ser sentida no momento em que se acentua a velocidade de mudanças sociais, econômicas e políticas que definia o ambiente empresarial. Na medida em que se modificam as condições ambientais, altera-se não só a possibilidade de 
alcance dos objetivos e resultados indesejáveis como também o que é desejável. Daí a necessidade de se desenvolver alternativas ou açóes potenciais que direcionam e possibilitam o redirecionamento constante dos objetivos e dos caminhos da organização (MOTTA, 1998, p. 82-83).

O conceito de estratégia, associado ao planejamento, popularizou-se no meio empresarial na década de 60, quando as grandes organizações sentiram a necessidade de aperfeiçoar seus processos de planejamento e gerência e mantiveram-se alertas para possíveis modificações futuras. Nessa época, a visão predominante na teoria administrativa ainda era a de explorar ao máximo as dimensões racionais da gerência para dominar as ambigüidades que surgiam no meio ambiente, valorizando o aperfeiçoamento de métodos racionais de ação administrativa para produzir maior eficiência e eficácia na antecipação das mudanças. Assim, o planejamento estratégico viria preencher a necessidade de utilizar métodos mais racionais e analíticos na criação de futuros alternativos (MOTTA, 1998).

A partir da década de cinqüenta, a questão de planejar de forma estratégica começou a chamar a atenção dos administradores com o desenvolvimento da abordagem contingencial, na qual, é descrito o nível estratégico como um dos três níveis organizacionais, sendo compreendidos em várias conotaçôes.

O planejamento estratégico, como aponta Motta (1998), é conseqüência direta da aquisição da perspectiva sistêmica e contingencial em administração, partindo da premissa de um ambiente em constante mutação e turbulência que determina possíveis variações no senso de missão sócio-econômica da organização. Foi introduzida uma visão ampla desta organização, conforme sua inserção no contexto social, econômico e político, e não mais limitada à natureza do negócio ou dos objetivos individuais da mesma. 
A abordagem contingencial salienta que não se atinge a eficácia organizacional seguindo um único e exclusivo modelo organizacional. Assim, não existe uma forma única e perfeita de organização para o alcance de objetivos variados das organizaçóes, dentro de um ambiente também variado (CHIAVENATO, 2000).

A visão contingencial procura analisar as relaçōes entre a organização, o seu ambiente e a tecnologia, onde, para se confrontar com os desafios externos, impostos pelo ambiente, e os desafios internos, impostos pela tecnologia, as organizaçóes, que se desdobram em três níveis organizacionais (Figura 3), descritos a seguir (PARSONS apud CHIAVENATO, 2000):

O nível institucional ou estratégico corresponde ao nível mais elevado da empresa, composto pelos diretores, proprietários ou acionistas e altos executivos. É o nível em que as decisōes são tomadas e os objetivos da organização são estabelecidos, bem como as estratégias para alcançá-los. Por manter uma interface com o ambiente, lida com a incerteza.

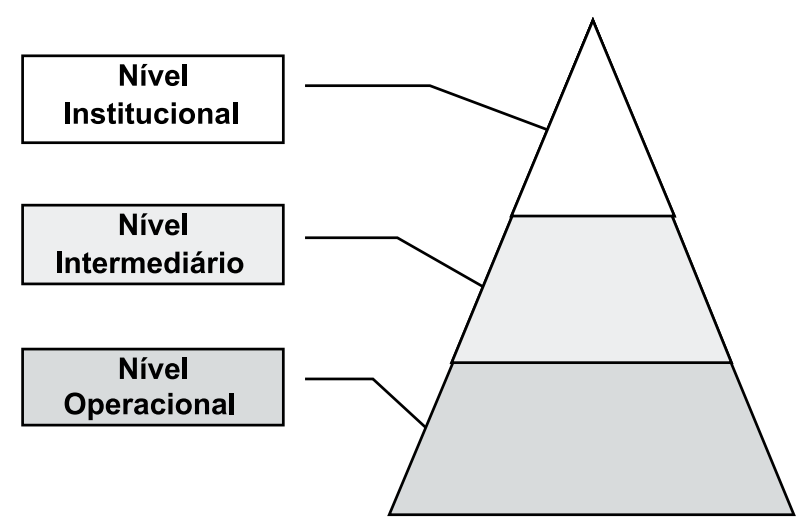

Figura 3 - Os Níveis Organizacionais.

Fonte: Adaptado de Massarollo (1991, p. 27).

Já o nível intermediário, também chamado nível mediador ou nível gerencial, encontra-se entre o nível institucional e o nível 
operacional, e cuida da articulação interna entre estes dois níveis. Atua na escolha e capacitação dos recursos necessários, bem como na distribuição e disposição da produção da empresa nos diversos segmentos do mercado; lida com problemas de adequação das decisões tomadas no nível institucional com as operações realizadas no nível operacional.

O nível operacional, também denominado nível técnico ou núcleo técnico, é localizado nas áreas inferiores da organização, onde as tarefas são executadas e as operações são realizadas. 


\section{4 \\ Planejamento normativo e estratégico}

A concepção de planejamento desenvolvida por Matus, e apontada por diversos autores, entre eles Azevedo (1992) e Silva (1994), está baseada em uma profunda crítica à teoria e prática do planejamento econômico-social, apontando o fracasso do planejamento enquanto livro-plano, ou seja, enquanto documento normativo. Essa concepção baseia-se na premissa de que, como a realidade muda constantemente, é preciso que o planejamento seja a mediação entre o conhecimento e a ação, e assim, continuamente construído, considere o futuro como parte desse processo de planejamento.

Ajudando a diferenciar o planejamento tradicional ou normativo das proposições de Carlos Matus, apontamos aqui algumas das principais questões analisadas por este autor (ver também o Quadro 1):

O planejamento normativo pressupõe uma distinção nítida entre sujeito e objeto do planejamento, sendo este último passível de controle. No Planejamento Estratégico Situacional (PES) o sujeito está inserido no objeto, isto é, faz parte da realidade planejada, que, por sua vez, contém outros sujeitos que também planejam (MATUS, 1993).

Para este autor, no PES o conhecimento é sempre situacional e depende da inserção de cada ator nessa realidade, sendo assim, 
ele é parcial e múltiplo. Já no planejamento normativo é possível um conhecimento único e objetivo da realidade.

$\mathrm{O}$ autor considera que a capacidade de previsão do planejamento normativo refere-se à confecção de leis e ao funcionamento social, podendo reduzir os acontecimentos em comportamentos previsíveis. Em sua concepção, a capacidade de previsão é um processo criativo que depende da interação entre os atores e requer um cálculo interativo além de um julgamento estratégico.

O planejamento normativo formula um "deve ser" imaginado num contexto de harmonia e ordenação, não considerando a existência do outro como sujeito. O planejamento de Matus entende a realidade como conflitiva, em que coexistem diversos atores com objetivos distintos. Refere-se, portanto, a um "pode ser" e à "vontade de fazer" (MATUS, 1993).

Este autor afirma que o planejamento normativo trabalha com a predição ou previsão probabilística, ou seja, uma incerteza bem definida, enquanto no PES tudo está impregnado de forte incerteza, e o plano combina apostas bem fundamentadas com apostas difusas, existindo a incerteza dura.

Matus (1993) afirma que, no planejamento normativo, os problemas podem ser resolvidos pela normatização, pois diz respeito a problemas bem estruturados ou os considera como tal. O planejamento estratégico situacional refere-se a problemas sociais, portanto, problemas quase estruturados que requerem ação criativa.

Para Matus (1993), o planejamento é um cálculo situacional que articula diferentes horizontes de tempo e envolve múltiplas dimensões da realidade. O cálculo situacional pode ser entendido como a análise de um ator social sobre a realidade, estando por ela envolvido. $\mathrm{O}$ ator insere-se em uma realidade concreta, onde existem outros atores, inclusive oponentes, que também planejam. 
Quadro 1 - Algumas características que diferenciam o planejamento tradicional do PES

\begin{tabular}{|l|l|}
\hline \multicolumn{1}{|c|}{ PLANEJAMENTO TRADICIONAL } & \multicolumn{1}{c|}{ PES } \\
\hline Determinista (predições certas) & Indeterminista (predições incertas) \\
\hline Objetivo (diagnóstico) & Subjetivo (apreciação situacional) \\
\hline Predições únicas & Várias apostas em cenários \\
\hline Plano por setores & Plano por problemas \\
\hline Certeza & Incerteza e surpresas \\
\hline Cálculo técnico & Calculo tecnopolítico \\
\hline Os sujeitos são agentes & Os sujeitos são atores \\
\hline Sistema fechado (metas únicas) & Sistema aberto (várias possibilidades) \\
\hline Teoria do controle de um sistema & Teoria da participação em um jogo \\
\hline
\end{tabular}

Fonte: O Método PES - Roteiro de Análise Teórica (material elaborado para o curso "Governo e Planejamento" FUNDAP - Fundación Altadir) (apud TANCREDI et al., 1998, p. 29). 


\section{5 \\ Planejamento em saúde na América Latina}

\subsection{A CEPAL e a introdução da idéia do planeja- mento na América Latina}

A CEPAL (Comissão Econômica para a América Latina) pode ser apontada como o núcleo inicial de difusão da ideologia de planificação na América Latina, e seus esforços preliminares

[...] centraram-se na elaboração de uma 'teoria do desenvolvimento' e na 'formação de uma consciência' e amplos grupos de intelectuais do continente. Este movimento planejador foi se apresentando progressivamente como um 'instrumento da formação de consciência' e com um 'instrumento de ação', mesmo não dispondo de um método previamente elaborado (PAIM, 1983, p. 68).

Paim (1983) afirma que o discurso planejador alcançou a plenitude nas recomendações da Carta de Punta del Este, que afirmava a necessidade de se impulsionar respostas, alentando a formulação de planos de desenvolvimento. Assim, a planificação social proposta por esta carta favoreceu o desenvolvimento do discurso planejador, a elaboração de técnicas e a formação de intelectuais que deram coerência a este discurso e procuraram legitimá-lo através da abordagem científica para a intervenção na realidade social (PAIM, 1983). 
Rivera (1992) afirma que o pensamento cepalino pode ser desdobrado em dois momentos: o momento economicista, correspondente à década de 50, que enfatizava o objetivo do crescimento econômico como sustentáculo do desenvolvimento; e o movimento sócio-político, da década de 60 , onde o desenvolvimento deixava de ser visto como um processo dependente apenas do crescimento econômico e passou a ser olhado como um processo global, que inclui as estruturas políticas e sociais.

Conforme Paim (1983), o desenvolvimento do planejamento de saúde na América Latina pode ser dividido, didaticamente, em quatro momentos. São eles:
1. Elaboração
2. Difusão e autocrítica
3. Revisão
4. Reatualização

No que se refere ao primeiro momento, o da elaboração, há o reconhecimento da técnica CENDES/OPS (Centro Nacional de Desenvolvimento/Organização Pan-americana de Saúde, da Universidade Central da Venezuela), como um marco do desenvolvimento do planejamento da saúde na América Latina. Essa técnica buscava na micro-economia os procedimentos para a melhor utilização dos recursos em saúde e privilegiava a programação local de modo que os planos regionais e estaduais constituíssem o somatório dos planos locais, até chegarem a um Plano Nacional de Saúde.

A técnica CENDES/OPS pode ser entendida como uma inovação conceitual e metodológica que contribuiria para a preparação dos planos nacionais de saúde, já que o setor saúde não tinha um método que assegurasse a compatibilidade do planejamento de saúde com o planejamento em outros setores, predominantemente econômico (PAIM, 1983). 
Este técnica, segundo Mattos (1993), foi organizada por uma seqüência de etapas predefinidas, com tarefas precisas e limites cronológicos delimitados, compreendendo quatro etapas (Figura 4):

1. Descrição e explicação da situação (diagnóstico).

2. Elaboração da programação propriamente dita (planejamento).

3. Implementação da programação.

4. Avaliação.

Atualmente, o método CENDES/OPS, pelo seu mecanicismo e baixa praticidade, sofre uma alta rejeição e pode ser considerado um enfoque normativo da programação do setor saúde (MATTOS, 1993).

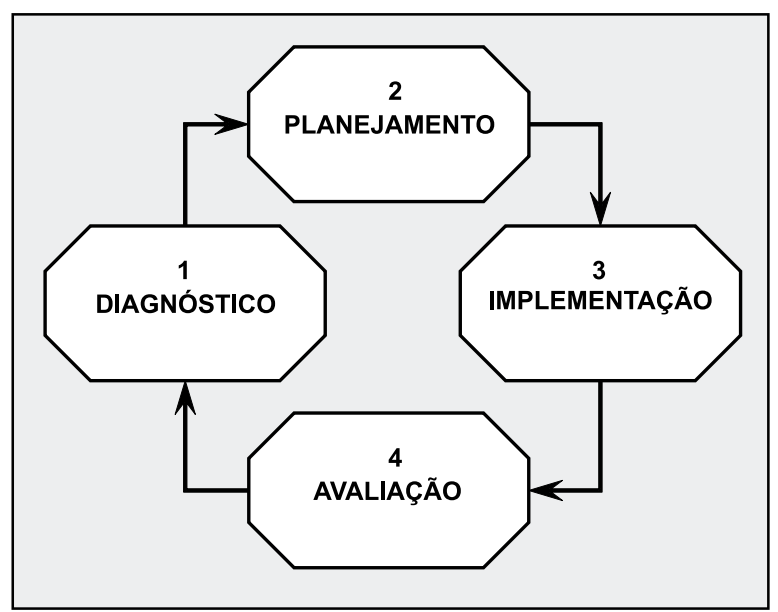

Figura 4 - O Método CENDES/OPS.

Quanto ao segundo momento, o da difusão e autocrítica, este se caracteriza por uma espécie de autocrítica do planejamento social e da saúde, tendo como um dos principais motivos 
estimuladores desta autocrítica, os planos nacionais de saúde que foram documentos que nunca se implementaram, uma vez que os organismos globais de planejamento não utilizaram as Unidades de Planejamento dos Ministérios da Saúde como órgãos de planejamento setorial, nem viabilizaram a sua coordenação. Tal situação provocou, no setor saúde, a perda da gravitação e utilidade como instrumento de estratégia política. Apesar disso, o movimento pelo planejamento de saúde se desenvolveu com a incorporação de técnicas de programação do setor público por alguns países, sendo que, no caso da saúde, a técnica CENDES/ OPS disseminou e legitimou o discurso do planejamento apesar da sua inefetividade (PAIM, 1983).

No terceiro momento, o de revisão, as deficiências metodológicas passaram a ser supridas através do desenvolvimento de métodos para objetos não cobertos pela CENDES/OPS, tais como inversōes físicas, recursos humanos, informação, decisão e controle. Procedeu-se uma revisão do marco conceitual, com ênfase nos aspectos organizacionais (sistêmicos) e políticos, assimilando as modernas técnicas de gestão, desenvolvendo as noçôes de eficiência, eficácia e efetividade, reconhecendo também a importância de variáveis políticas, em vez de técnicas, na alocação de recursos (PAIM, 1983).

A reatualizaçáo, quarto momento, tem como marco o aparecimento do texto "Formulacion de las politicas de Salud" elaborado por técnicos do CPPS (Programa Pan-americano de Planificação de Saúde), indicando um deslocamento do micro-econômico para o político, e servindo como um guia para a formulação de políticas, ainda que reconhecida a possibilidade de um risco tecnocrático. Constitui-se numa proposta complementar à técnica CENDES/OPS, como uma resposta racionalizadora para a crise do setor saúde (PAIM, 1983). 


\subsection{A consolidação do enfoque estratégico (tipos de planejamento estratégico)}

Como observa Rivera (1992), na América Latina, o denominado enfoque estratégico de planificação ganha força a partir de 1975, principalmente na década de 80 , em função da crítica à planificação normativa e da configuração do enfoque estratégico de planificação.

Com base neste enfoque e na nova configuração de planejamento, podemos extrair três vertentes que contrapóem o modelo dominante de planejamento normativo em saúde (LANA; GOMES, 1996):

- Enfoque Estratégico da Programação em Saúde, formulação feita pela Escola de Saúde Pública de Medellin, em 1975;

- Pensamento Estratégico, elaborado por Mário Testa, sanitarista argentino, em 1981;

- Planejamento Estratégico Situacional, elaborado por Carlos Matus, economista chileno, em 1982.

A tendência de Enfoque Estratégico da Programação em Saúde (da Escola de Medellin) foi apoiada pelo documento "Formulacion de las politicas de Salud" que, como referido anteriormente, representou um novo paradigma para explicar o setor saúde. O documento pretendia colaborar com conceitos e orientações sobre a formulação de políticas de saúde e concebia o sistema de saúde a partir de três componentes: o político, o técnico-político e o nível tático-operacional (LANA; GOMES, 1996).

O modelo básico, segundo Rivera (1992), prevê sete etapas: formulação de uma imagem-objetivo; comparação entre a imagem-objetivo e a situação inicial; definição dos projetos preliminares; análise de factibilidade; análise de viabilidade; definição de uma estratégia; formalização e implementação. 
Lana e Gomes (1996) apontam como grande mérito desse enfoque a contraposição, em 1975, à visão dominante do planejamento normativo, resgatando o caráter dinâmico, flexível, atrelado à conjuntura do planejamento e à importância do reconhecimento de que o planejamento envolve o enfrentamento e as confluências das forças sociais. Planejar passa a ser um ato político, cabendo ao planejador reconhecer-se neste papel, de técnico, com competência política.

A segunda vertente, a do Pensamento Estratégico (de Mario Testa), atribui a necessidade de mudanças no âmbito da política em geral, e tem uma visão de planejamento como instrumento capaz de auxiliar no cumprimento de uma única imagem-objetivo possível, a da acumulação e da desacumulação de poder. Esta proposta trabalha com três níveis de diagnósticos: o administrativo, o estratégico e o ideológico (RIVERA, 1992).

Segundo Testa (1992), o Diagnóstico Administrativo está voltado para a análise dos recursos, do acesso populacional aos serviços, da estrutura populacional e da enfermidade, nos termos elementares da planificação normativa associada ao propósito de aumentar a produtividade. Envolve as seguintes categorias básicas: o estado de saúde da população, a situação epidemiológica, os serviços de saúde, como uma resposta da sociedade aos problemas apresentados pelo estado de saúde e situação epidemiológica, e por fim, o estudo do setor saúde.

O Diagnóstico Estratégico, segundo este autor, está voltado para a análise das relaçôes de poder, associada ao propósito de mudança. Aqui, se estudam as relações de poder, ao nível das categorias básicas: o estado de saúde da população, a situação epidemiológica, os serviços de saúde e o setor saúde.

O mesmo autor considera que o Diagnóstico Ideológico procura identificar os aspectos técnico-ideológicos que conduzem à legitimação do poder como propósito e que são utilizados para a interpretação dos dois primeiros níveis de diagnóstico e 
para a imposição das idéias dominantes na sociedade. Este diagnóstico visa identificar quais os grupos sociais de sustentação e quais são os sistemas de idéias relacionados ao processo saúde/ doença. Envolve uma síntese diagnóstica, dinâmica e estratégica, onde seriam formuladas as propostas.

Testa (1992) acrescenta que o pensamento estratégico em saúde admite três tipos de poder: o administrativo, o político $\mathrm{e}$ o técnico.

Entende como poder técnico a capacidade de gerar, aprovar, manipular informações de características distintas, com vários aspectos (médico, sanitário, administrativo etc.) e operando em múltiplos âmbitos, que são: a docência, a pesquisa, os serviços, a administração superior e a população.

O poder administrativo, conforme Testa, é a capacidade de apropriar-se dos recursos e alocá-los. Resume-se, quase totalmente, às diversas formas de financiamento.

Quanto ao poder político, Testa afirma que é a capacidade de mobilizar grupos sociais que demandam ou reclamam suas necessidades e interesses. A capacidade de desencadear uma mobilização vai depender de uma visão da realidade que é um saber gerado de maneiras diversas e agrupado em duas grandes categorias: conhecimento empírico e conhecimento científico. Esse tipo de poder cruza-se com os poderes técnico e administrativo nas formas de saber científico com prática de dominação, e de saber empírico com prática hegemônica.

Quanto ao Planejamento Estratégico Situacional (de Carlos Matus), Rivera (1992) enfatiza que esse modelo de planejamento trabalha dois conceitos básicos: o de situação, com base fenomenológica e o da teoria da produção social, de base marxista. O Planejamento Estratégico Situacional será abordado de forma mais ampla, e aprofundada, no próximo capítulo a ele dedicado. 


\section{6 \\ O planejamento estratégico situacional}

A América Latina destacou-se no cenário mundial, onde se observa uma evolução do Planejamento Estratégico, cujo enfoque estratégico de planificação ganha força em função da crítica à planificação normativa feita por Carlos Matus, no início da década de setenta, culminando na elaboração, por este autor, em 1988, de uma das vertentes de planificação estratégica, denominada Planejamento Estratégico Situacional (PES) (RIVERA, 1992).

A intenção de Matus é justificar e desenvolver um conjunto de técnicas, métodos, destrezas e habilidades que permitam ao ator-protagonista em situação, aumentar suas capacidades de direção, gerência, administração e controle do sistema social no qual está inserido (BRASIL, 1995).

Por outro lado, o Planejamento Estratégico Situacional é descrito, pelo próprio Carlos Matus, como um corpo teórico-metodológico-prático sólido, sistemático e rigoroso. Como método e teoria do Planejamento Estratégico Público, o mais novo dos ramos do planejamento estratégico foi concebido para enfrentar os problemas públicos, sendo, também, aplicável a qualquer órgão cujo centro de jogo não seja exclusivamente o mercado, mas o jogo político, econômico e social (HUERTAS, 1996).

Matus advoga que o Planejamento Estratégico Situacional (PES) é potente para lidar com a complexidade da realidade 
social. Considerando a capacidade de planejamento de outros atores, a ocorrência de surpresas e a existência de incertezas, o método nos reporta a encarar a realidade com todas as suas nuances, o que significa que, obviamente, não é possível trabalhar com relações diretas de causa e efeito (TANCREDI et al., 1998).

Matus, em entrevista com Huertas, afirma:

O mundo do planejamento tradicional limita-se ao sócio econômico. O PES, ao contrário, aspira a ser, e chegou a ser, um planejamento da ação humana que integra todas as dimensões da realidade, especialmente o mundo da política e da técnica (HUERTAS, 1996, p. 29).

Para Tancredi et al. (1998), o Planejamento Estratégico Situacional privilegia a idéia de momento e situação considerando que: uma mesma realidade pode ser explicada mediante situações diferentes, porque os atores do jogo social participam dele com diferentes propósitos; o conceito de situação obriga a determinar quem explica, ou seja, toda explicação credita alguém a partir de uma posição no jogo social; a análise situacional obriga a diferenciar as explicações, ou seja, cada ator avalia o jogo social de modo particular e atua segundo sua própria interpretação da realidade; a categoria situação permite compreender a assimetria das explicaçōes em um jogo social, conceito teórico da maior importância na análise estratégica.

Consideremos que momento, como afirma Matus (1993, p. 297), compreende "[...] instância, ocasião, circunstância ou conjuntura pela qual passa um processo contínuo, ou em cadeia, que não tem começo nem fim definidos." Onde, dentro do processo de planejamento, esses momentos encadeiam-se e compóem circuitos repetitivos para amparar-se mutuamente e passar sempre à um outro distinto.

$\mathrm{O}$ autor complementa ainda que, dessa forma, nenhum momento começa ou termina no tempo preciso, nem é 
necessariamente anterior ao outro, nem fecha ou termina o processo encadeado, bem como, não fica definitivamente para trás, nem se esgota numa só instância. Desse modo, volta a repetir-se outras vezes no futuro, para transitoriamente dominar.

Por privilegiar a idéia de momento, o PES supera a visão linear implícita no conceito de etapa, distinguindo quatro momentos (Figura 5): explicativo (seleção, descrição, e explicação de problemas); normativo (desenho de um plano por operações para enfrentar os problemas); estratégico (análise de viabilidade política do plano e desenho de uma trajetória estratégica); e momento tático-operacionai, da gestão e da implementação do plano (RIVERA, 1996).

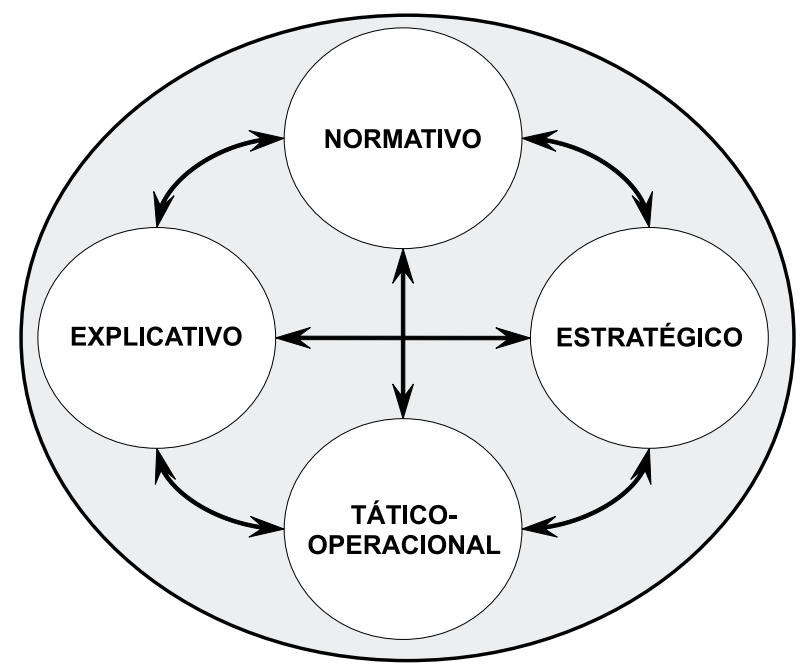

Figura 5 - Os quatro momentos do planejamento estratégico situacional.

Para Matus, planejamento é um cálculo situacional e sistemático, que articula diferentes horizontes de tempo e envolve múltiplas dimensões da realidade. É definido, portanto, pela qualidade, profundidade e sistematicidade deste cálculo, sendo seu 
objeto o próprio movimento social, a dinâmica de produção e reprodução da sociedade (SILVA, 1994).

O Planejamento Estratégico Situacional surgiu exatamente para preencher as lacunas deixadas pelo planejamento normativo, contribuindo para suprir as necessidades, e desafiar as constantes mudanças, servindo de guia para as alteraçōes nas açōes gerenciais dos indivíduos no interior das organizaçôes. Apesar de originado do âmbito do planejamento econômico social, o PES tem sido alargado ao campo da saúde enquanto iniciativa política da Organização Pan-americana de Saúde (OPS) (RIVERA, 1992).

O pensamento estratégico, aplicado ao planejamento em saúde, surgiu no final da década de 70 , como meio para superar os problemas inerentes à formulação normativa de planos, cujo paradigma encontra-se representado no método elaborado pelo Centro Nacional de Desenvolvimento / Organização Pan-americana de Saúde - CENDES/OPAS (BRASIL, 1995). Essa nova proposição resultou, em suas primeiras manifestações no âmbito da saúde, das reflexões de Testa (1995), que foi, também, protagonista fundamental da elaboração do método CENDES/OPAS.

É também considerado como um tipo de planejamento que se contrapõe ao modelo dominante normativo, em saúde, criticando, basicamente, o privilégio da lógica economicista e administrativa no estabelecimento de prioridades, privilegiando o planejamento como instrumento básico e necessário ao processo de transformação (LANA; GOMES, 1996).

Artmann (2000), citando Matus, acrescenta que o PES é um método de alta complexidade e alta potência, adequado para o nível diretivo de instituições de grande porte e com pessoal especializado.

Buscando enfrentar a questão da operacionalização de um método complexo e sofisticado no nível local, Matus combina dois outros métodos para formar um sistema de planejamento (Trilogia Matusiana), dirigido aos distintos níveis gerenciais de 
uma organização ou organizações de diferentes complexidades. Formam a trilogia, o PES, o ZOPP (Planejamento de Projetos Orientado por Objetivos) e o MAPP (Método Altadir de Planificação Popular) desenhados, respectivamente, para os níveis institucional/central, intermediário e operacional/local (Figura 6). O autor sugere a combinação desses métodos, segundo a hierarquia e a complexidade dos problemas abordados, destacando a coerência e identidade de concepção metodológica entre eles (SILVA, 1994; ARTMANN, 2000).

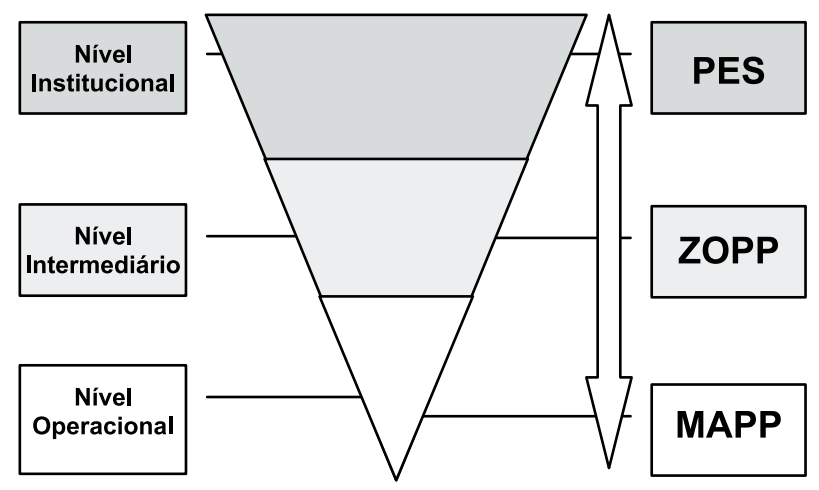

Figura 6 - A Trilogia Matusiana.

Tancredi et al. (1998) reforçam que a preferência de um ou outro desses métodos deve considerar o nível organizacional (estratégico, intermediário e operacional) no qual se pratica o planejamento, a natureza do trabalho, a complexidade dos problemas e a capacidade do governo.

Para Matus, muitas vezes a combinação desses métodos pode ser útil. Chama a atenção para o fato de que, nos níveis locais e intermediários, também se apresentam problemas estratégicos, havendo necessidade, portanto, de uma análise de viabilidade mais aprofundada. Ao contrário do ZOPP, que abandona as alternativas não viáveis na situação inicial, o PES propõe a construção de viabilidade para o plano. Sendo o ZOPP e o MAPP 
bastante limitados nesse aspecto, Artmann (2000) propõe a operacionalização do PES mesmo no nível local, com as adaptações necessárias, tendo-se o cuidado de não simplificá-lo a ponto de fazê-lo perder a potência na abordagem global e estratégica dos problemas.

\section{A) O planejamento de projetos orientado por obje- tivos - ZOPP}

O ZOPP (sigla em alemão para: Zielorientierte Projektplanung - Ziel $=$ objetivo; Orientierte $=$ orientado; Projekt $=$ projeto; Planung = planejamento) é um método desenvolvido pela GTZ (Deustsche Gesellscchaft für Technische Zusammenarbelt - Sociedade Alemã de Cooperação Técnica), tendo como princípio básico o enfoque participativo, ou seja, a participação ativa no planejamento do projeto de todos aqueles que estarão diretamente envolvidos, sendo estes, em alguns casos, os próprios beneficiários (HELMING; GÖBEL, 1998).

Este método é caracterizado, segundo Helming e Göbel (1998), por um procedimento gradual através de uma seqüência de etapas sucessivas e interligadas de planejamento, permanente visualização e documentação de todas as etapas do planejamento, e enfoque no trabalho em equipe.

Originalmente voltado para a elaboração de projetos de desenvolvimento realizados por meio de cooperação internacional, Matus fez algumas alterações no formato original alemão para integrar o sistema PES, objetivando um método de complexidade intermediária, próprio para ser utilizado em níveis operacionais e específicos (Silva, 1994; BURSZTYN; RIBEIRO, 2005).

Este método fornece uma linha de raciocínio e procedimento consistentes e a compreensão uniforme dos termos usados. Assim, ele facilita a comunicação e a cooperação entre as partes envolvidas (HELMING; GÖBEL, 1998). 
Segundo esses autores, a linha de raciocínio e procedimentos se dá a partir de uma lógica interna baseada nos seguintes princípios:

- A cooperação entre diversas pessoas e/ou organizações funciona melhor se houver um consenso de todos sobre alguns objetivos precisos e claros.

- O trabalho na solução de problemas é tanto mais eficaz quanto maior for o grau de conhecimento das suas causas.

- A análise dos problemas, suas causas e efeitos, são considerados muito úteis para determinar os objetivos realisticamente alcançáveis.

- A análise dos problemas é tanto mais completa e realista quanto melhor for a análise das pessoas, grupos e organizações envolvidos, porque os problemas e suas causas nunca estão dissociados de pessoas, grupos ou organizaçôes.

O ZOPP, conforme Bursztyn e Ribeiro (2005), compreende as etapas de diagnóstico, priorização de problemas e construção do plano, os quais compōem módulos relativamente independentes e podem ser aplicados de maneiras variadas, dependendo da situação concreta.

Nesse método de planejamento, são percorridos doze passos, partindo-se da análise participativa para, em seguida, identificar e analisar os problemas centrais, a relação causa-efeito, e transformar a hierarquia de problemas numa hierarquia de objetivos. Depois se identificam as soluçóes alternativas. A matriz de planejamento de projeto relaciona a descrição do problema com os indicadores de objetivos (metas), dados, e as suposiçōes do que deve ocorrer no projeto. O controle do projeto é rigorosamente definido pelas fontes de comprovação de cada etapa (HELMING; GÖBEL, 1998). 


\section{B) O método Altadir de planificação popular - MAPP}

O MAPP, por sua vez, é uma simplificação do método ZOPP, realizado pela Fundação Altadir, e se baseia nos mesmos princípios do PES, sendo um bom método a ser operacionalizado no nível popular, associações de moradores e instituições de pequeno porte (Silva, 1994), ou seja, aplica-se à planificação tático-operacional de unidades, de sistemas locais menos complexos, ou de programas específicos de ação. Tancredi et al. (1998) acreditam que o emprego do MAPP é mais pertinente a sistemas municipais de cidades de pequeno porte e situações de menor complexidade.

$\mathrm{O}$ uso do MAPP permite uma visão sistêmica dos problemas, pela identificação da rede de causas geradoras e mantenedoras do evento, além de estabelecer objetivos e metas que se constituem em referência para o desenvolvimento das atividades (BARBOSA, 2000).

Esse método se fundamenta nos mesmos princípios do PES e, pelas suas características operativas, constitui-se no método de eleição para planejamento em nível local, particularmente aqueles altamente descentralizados. É simples e criativo, elaborado com o objetivo de viabilizar o planejamento a partir de uma base popular. Favorece o comprometimento da comunidade e de suas lideranças com a análise e o enfrentamento de seus problemas (TANCREDI et al., 1998)

De acordo com Tancredi et al. (1998), aplica-se à solução daqueles problemas limitados ao espaço mais restrito do nível local, assim como àqueles que não se constituam numa rede de relações muito complexas. É, portanto, um método bastante coerente com os princípios do SUS. É recomendado que o processo de planejamento seja desenvolvido em oficinas de trabalho, reunindo funcionários da saúde, membros da comunidade, lideranças e monitores da Secretaria de Saúde. A proposta é que os membros da equipe de trabalho sejam atores ativos no processo 
de elaboração do planejamento. Cada oficina deve ter como objetivo a elaboração de um produto e, ao seu término, algumas tarefas serão definidas para as oficinas seguintes.

O MAPP é desenvolvido em doze passos, que vão desde a seleção, descrição e explicação do problema, desenho da situação objetiva e das operaçôes, definição dos atores responsáveis pelas operações e monitorações das ações e recursos, análise de viabilidade e vulnerabilidade do plano, bem como o desenho do sistema de prestação de contas. A saber:

1. Busca da identificação de insatisfações.

2. Descrição de problemas.

3. Análise de suas causas e conseqüências.

4. Definição de objetivos.

5. Identificação de causas críticas.

6. Seleção e desenho de operações para atacar as causas principais dos problemas.

7. Definição dos recursos e orçamentos.

8. Identificação dos atores relevantes para geração, manutenção e enfrentamento dos problemas e sua motivação face às ações desenhadas.

9. Análise dos recursos críticos para enfrentar um problema, e aplicação sumária dos conceitos de peso, poder e força dos atores.

10. Análise da trajetória ou seqüência temporal do plano.

11. Analise da vulnerabilidade do plano.

12. Avaliação do desempenho dos responsáveis pelo plano.

\subsection{Planejamento como método de governo}

O enfoque de planejamento desenvolvido por Matus, segundo Azevedo (1992) e Silva (1994), parte da articulação entre 
o setor de planejamento e o governo, inspirado na reflexão e na experiência deste autor sobre o processo de governo. "Pretendendo resgatar o planejamento como método de governo, como ferramenta útil, flexivel e eficaz para lidar com as necessidades da direção em cada lugar da administração pública" (AZEVEDO, 1992, p. 130). Governar, para Matus, está se referindo ao Governo do Estado, tendo o aumento da eficácia da ação governamental e a melhoria do desempenho do dirigente estatal de alto nível como foco de sua preocupação principal (SILVA, 1994).

Azevedo (1992) acrescenta que o governo se refere ao comando de um processo, não apenas do Estado, mas também de um ministério, sindicato ou unidade de saúde.

Percebe-se, aqui, que a concepção de governo torna-se ampliada, pois Matus (1993) admite que governar e planejar não são uma prerrogativa exclusiva do Estado, mas de toda a sociedade, e de suas representações, que tentam transformar a realidade e construir um modelo almejado. Segundo Matus (1993), as forças sociais governam, em alguma medida, nos diversos âmbitos da sociedade.

Silva (1994), citando Matus, chama atenção para o uso do "g" minúsculo na palavra governo, com o objetivo de destacar que o planejamento e o governo de processos são capacidades potenciais de todas as forças sociais e de todos os homens. Dessa forma, reforça o entendimento da reflexão de Matus como extensiva aos diversos setores sociais, à gestão de vários sistemas organizativos, incluindo todos os níveis de direção.

Para Matus (1993), a tomada de decisões é responsabilidade de quem governa, de quem conduz. Neste sentido, planeja quem governa, quem tem a capacidade de decidir, de conduzir. Como salienta Azevedo (1992), a única forma do planejamento funcionar é respondendo às necessidades de quem gerencia e às dos atores sociais em questão. Assim, entende-se que o planejamento situacional é uma forma de organização para a ação, sendo esta a diferença fundamental em relação ao planejamento tradicional. 
Para Matus (1993), governar é um processo complexo que envolve três variáveis interdependentes que constituem um sistema triangular denominado de Triângulo de Governo (Figura 7); são elas: o projeto de governo, a governabilidade e a capacidade de governo. "O modelo de triângulo de governo permite compreender o processo de governo ou arte de conduzir como dependente da interação e mútuo condicionamento entre as três variáveis referidas" (SILVA, 1994, p. 5). Governar é buscar a articulação entre a ciência e a arte destas variáveis.

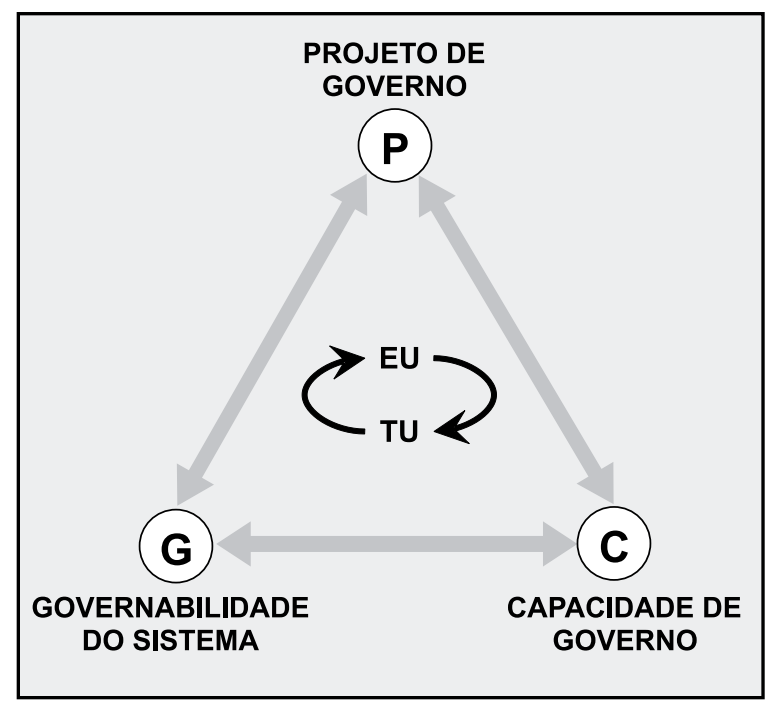

Figura 7 - O Triângulo de Governo.

Fonte: (MATUS, 1993, p. 60).

Conforme descreve Matus (1993), o projeto de governo (P) refere-se ao conteúdo programático dos projetos de ação que um ator pretende realizar para alcançar os objetivos pré-estabelecidos. A conformação desse projeto depende, não apenas das circunstâncias e interesses do ator que governa, mas, também, de sua capacidade de governo, ou seja, de suas possibilidades de ação e de sua capacidade para desenhar propostas relativamente elabo- 
radas e criativas. Para governar, uma equipe dirigente necessita selecionar objetivos, dimensioná-los a partir das circunstâncias presentes, de seus interesses, de seu programa, e expressá-los em seu projeto de governo.

O sistema em que está inserido este projeto não é passivo. As resistências e apoios indicam uma relação de forças em que é possível verificar a maior ou menor sustentação política para que o ator social que governa possa implementar seu projeto.

Para o autor, a governabilidade do sistema (G) diz respeito à relação entre as variáveis controladas, ou não, pelo autor, no processo de governo. É o poder de fogo que o ator tem para decidir e realizar o que foi decidido. Dessa forma, quanto mais variáveis decisivas ele controla, maior é a possibilidade de realização do seu projeto. $\mathrm{O}$ ator pode ter governabilidade alta, média ou baixa, em relação a problemas diferentes. A governabilidade pode ser alta, quando a solução de um problema depende apenas de nós. Quando a solução depende de outros, a governabilidade pode ser média ou baixa.

A governabilidade é sempre relacionada a um ator específico, e está sempre dependendo do grau de exigência, da demanda do seu projeto e da sua capacidade de governo.

A capacidade de governo $(\mathbf{C})$, para o autor, está relacionada à capacidade de direção ou condução de um ator; refere-se, também, ao conjunto de técnicas, métodos, destrezas, habilidades e experiências disponíveis a um ator. A governabilidade e o conteúdo do projeto de ação condicionam a capacidade de governo, ao mesmo tempo em que esta constitui um meio para ampliar a governabilidade e desenhar projetos eficazes.

Neste sentido, "a capacidade de governo constitui o objeto nuclear do trabalho de Matus e é neste âmbito que o planejamento se insere, como um dos elementos mais importantes da definição desta capacidade" (SILVA, 1994, p. 5). Nesse contexto, o planejamento é definido como um cálculo que precede e preside a ação, pres- 
supondo, ainda, um sujeito, um ator social inserido na realidade planejada; é definido, também, como interação e conflito com outros atores, visando à ação e ao alcance de objetivos.

\subsection{A metodologia do planejamento estratégico situacional}

A metodologia de planejamento estratégico situacional concebido por Matus está estruturada em quatro momentos que podem ser recursivos e não-lineares, mas que representam um seqüenciamento lógico da elaboração teórica do planejamento. São eles o momento explicativo, o normativo, o estratégico e o tático-operacional.

O conceito de momento é a base da lógica interna do processo de planejamento. Porém, é necessário saber se estes não se confundem com etapas do processo. A idéia de momento indica instância, circunstância ou conjuntura de um processo contínuo que não tem início ou fim determinado. O que ocorre é um domínio passageiro de um momento sobre os demais ao longo do processo. Silva (1994, p. 9) reforça:

[...] nesse sentido, cada momento da metodologia corresponde ao domínio transitório de determinados conteúdos, passos e procedimentos específicos. Estes, no entanto, não são de uso exclusivo de cada momento, o que possibilita um encadeamento flexível e dinâmico entre eles.

O conceito de momento sugere numa visão dinâmica do processo de planejamento, que se distingue pela constante interação de suas fases ou momentos e pela constante retomada dos mesmos. Cada um dos momentos do PES possui suas ferramentas metodológicas especificas que podem ser retomadas no demais (MATUS, 1993). 
Com base na obra de Matus (1993), segue-se uma breve descrição dos quatro momentos do planejamento situacional:

\subsubsection{Momento explicativo (M1)}

É aquele onde se está indagando sobre as oportunidades e problemas que enfrenta o ator que planeja, buscando, antes de tudo, explicar suas origens e causas. Relaciona-se com a compreensão do que foi e do que tende a ser a realidade. É onde se realiza a explicação dos problemas a partir dos conceitos de situação e da teoria da produção social.

Nesse momento, ocorre a seleção dos problemas e a descrição dos mesmos através de indicadores e ou descritores que o definem com clareza, ou seja, sem confundi-lo com outros ou com suas próprias causas e conseqüências.

Após a descrição, os problemas devem ser analisados através da construção de uma rede de causalidade, usando o Fluxograma Situacional no PES, ou a Árvore de Problemas no ZOPP e no MAPP.

Para Matus, os problemas estratégicos estão sempre entrelaçados com outros problemas, podendo-se identificar causas que são comuns a vários problemas que se manifestam inclusive em diferentes setores.

Toni (2006) ressalta que no planejamento tradicional a realidade é dividida em setores e o método dos planejadores é tão fragmentado quanto são os departamentos dos órgãos de planejamento. O planejamento estratégico situacional propõe trabalhar com o conceito de problemas. Nele a realidade é composta de problemas, oportunidades e ameaças. Este tipo de planejamento permite sintetizar a noção de explicação da realidade em suas múltiplas dimensões (interdisciplinar) com a noção de direcionalidade do ator: saber selecionar e identificar problemas reais (atuais ou potenciais) e distinguir causas de sintomas e conseqüências 
já é mudar radicalmente a prática tradicional dos "diagnósticos" convencionais. Explicar a realidade por problemas também permite o diálogo e a participação com setores populares que afinal sofrem problemas concretos e não "setores" de planejamento.

\subsubsection{Momento normativo (M2)}

Após a identificação, seleção e priorização de problemas, bem como o debate sobre as causas, sintomas e efeitos, surge o momento para desenhar o conjunto de açôes ou operaçôes (programa direcional) necessárias e suficientes para atacar as causas fundamentais dos problemas (também chamadas de Nós Críticos).

$\mathrm{O}$ momento normativo corresponde ao desenho de como "deve ser" a realidade, que, no planejamento tradicional, se confunde com todo o processo de planejamento. Significa a operação que supera os problemas cruciais (chamados de nós críticos), permitindo estabelecer as operações que, em diferentes cenários, levou à mudança da situação inicial em direção à situação objetivo.

Mas o desenho normativo incide também sobre como deve ser a estratégia (M3), como deve ser a decisão e a execução do plano (M4) e como deve ser a norma que serve de referência para explicar a situação presente (M1) e selecionar os problemas. Assim, embora o centro do momento normativo seja o "deve ser" do conteúdo do plano, os outros momentos do processo de planejamento estão sempre presentes.

A rede de causalidade, construída em M1, direciona a projeção de uma rede de resultados esperados, o que corresponde ao que Matus nomeia construção de uma árvore de apostas, no PES, e corresponde à Árvore de Objetivos, no ZOPP e no MAPP.

Para Toni (2006), o central neste modelo de planejamento é discutir a eficácia de cada ação e que situação objetiva sua realização, em cada projeto, e isso só pode ser feito relacionando os 
resultados desejados com os recursos necessários e os produtos de cada ação. Os planos normativos normalmente terminam aqui, onde o planejamento situacional apenas começa.

\subsubsection{Momento estratégico (M3)}

É o momento que vai do "pode ser" ao "como fazer". Onde o ator se pergunta: Como posso tornar viável o meu esboço normativo? Que obstáculos devo vencer e como vencê-los para que meu esboço se entranhe na realidade como uma força efetiva de mudança em direção à situação eleita como objetivo?

Para Matus, a estratégia não se refere ao cálculo do possível, mas à construção da viabilidade, por meio do gerenciamento de conflitos e de negociação, pois a arte da política consiste em fazer possível, amanhã, aquilo que, hoje, parece impossível.

Inclui a formulação de uma estratégia e a análise da viabilidade em três níveis: a viabilidade política (que supõe negociações para acordar vias comuns de ação, através de renúncias recíprocas); a viabilidade econômica (que deve responder se são viáveis, economicamente); e a viabilidade institucional-organizativa (que terá de responder se a capacidade organizativa é capaz de sustentar o programa direcional).

Este momento relaciona-se à viabilidade e, portanto, aos obstáculos a serem vencidos para aproximar a realidade da situação eleita como objetivo. É nesse momento que se deve efetuar o cálculo para a superação dos obstáculos colocados para a efetivação de mudanças, sejam eles relativos à escassez de recursos econômicos, políticos ou institucionais-organizacionais.

Toni (2006) afirma que toda estratégia é uma exploração consciente do futuro e resulta da situação diferenciada dos vários atores em relação à problemas, oportunidades e ameaças. Dois instrumentos-processos cabem aqui: a análise de cenários e a 
análise criteriosa dos demais atores sociais ou agentes. Os cenários representam distintas reflexões, limitadas pela qualidade da informação disponível sobre possíveis "arranjos" econômicos, institucionais, políticos, sociais etc., capazes de influenciar positiva ou negativamente a execução das ações planejadas.

\subsubsection{Momento tático-operacional (M4)}

É entendido como o momento "do fazer", É um momento decisivo do planejamento situacional, já que o planejamento é concebido como cálculo que precede e preside a ação, as possibilidades ou o alcance do processo de planejamento que se dará pela capacidade de esse cálculo alterar, conduzir e orientar as ações presentes. Neste momento, corresponde à programação de curto, médio e longo prazo, incluindo a tomada de decisão, o controle e a avaliação.

É quando tudo se decide e por isso, do ponto-de-vista do impacto do plano, é o momento mais importante. Não podemos esquecer que o planejamento estratégico só termina quando é executado, é o oposto à visão tradicional do "plano-livro" que, separando planejadores de executores, estabelecia uma dicotomia insuperável entre o conhecer e o agir (TONI, 2006).

Neste momento, ocorre a gestão do plano porque, na visão do PES, planejamento e gestão são inseparáveis, o plano não é o desenho no papel, mas um compromisso de ação que visa resultados, impacto nos problemas selecionados, que se traduzem em novas situações mais favoráveis do que a situação inicial. 


\section{7 \\ Planejamento estratégico no gerenciamento de Enfermagem}

O papel do enfermeiro no passado caracterizava-se como provedor de cuidados de saúde, onde este profissional assumia o papel de várias outras áreas de conhecimento (fisioterapia, farmácia, nutrição e serviço social). Hoje o enfermeiro passou a coordenar e assistir ao cliente, permitindo a este se concentrar no corpo de conhecimento específico da Enfermagem (WILKINSON, 1992). Desta forma, exigindo dos profissionais de Enfermagem uma valorização das funções administrativas.

É muito comum dentro dos Serviços de Enfermagem a existência de administradores com o hábito de usar técnicas de gerenciamento baseadas na administração somente por objetivos, em que a preocupação é estabelecer objetivos a serem cumpridos no futuro, mas sem formulação estratégica. Ela tem levado a graves problemas gerenciais por limitar a ação administrativa no enfrentamento de objetivos que, na essência, são de natureza operacional (GERDES; ERDMANN, 1995).

Estas autoras, Gerdes e Erdmann, apontam como uma das razões para que isto ocorra, o fato de os profissionais (incluindo aí os enfermeiros), que detêm o poder formal de decidir estrategicamente nas organizaçóes, raramente questionarem o real motivo de se executar uma determinada tarefa, o que pode levá- 
-los a serem "absorvidos" pela inércia do processo, perpetuado por eles mesmos. Daí, a importância de se utilizar o planejamento em todas as atividades de Enfermagem.

No que se refere à questão de planejamento, Ciampone (1991, p. 41) afirma que "para os estudiosos da administração, o planejamento costuma figurar como a primeira das funçōes administrativas e uma das mais importantes, pois serve de base para as demais". Para a administração dos Serviços de Enfermagem essa afirmação é pertinente, pois se observa constantemente o uso de planejamento tanto para sistematizar o trabalho, como para prever mudanças e adequar os recursos, a fim de se atingirem os objetivos propostos. $\mathrm{O}$ ato de planejar está presente em todas as atividades de Enfermagem, sejam elas de caráter administrativo ou assistencial, como foi referido por Silva (2000, p. 13):

O gerenciamento administrativo [original sem grifo] consiste na coordenação de recursos (meios) para atingir os fins em uma instituição e grupo; o gerenciamento clínico [original sem grifo] consiste na coordenação da assistência prestada ao cliente, para que possam ser atendidas as suas necessidades básicas, ou seja, é agir sobre os fins [...].

A citada autora afirma, ainda, que os limites entre o gerenciamento administrativo e o gerenciamento clínico "são tênues e o enfermeiro sente isso mais que qualquer outro profissional, pois em geral tem que fazer as duas atividades nas unidades assistenciais, trazendo algumas vezes como conseqüência deficiências em ambos os processos" (SILVA, 2000, p. 13).

O gerenciamento clínico em Enfermagem é denominado por Castilho e Gaidzinski (1991) como "administração da assistência de Enfermagem", tendo como foco de atenção o paciente, visando ao atendimento das suas necessidades. Ele é orientado para a assistência, envolvendo o planejamento, a direção, a coordenação, a supervisão e a avaliação das atividades desenvolvidas pela equipe de Enfermagem no hospital. 
Segundo Castilho e Gaidzinski (1991, p. 209), o planejamento da assistência de Enfermagem é a "função que possibilita ao enfermeiro exercer a administração da assistência de Enfermagem de forma global, coerente e responsável", afirmando, ainda, que têm sido propostos vários métodos para o planejamento da assistência de Enfermagem, sendo esses métodos geralmente denominados de "Processo de Enfermagem"1 (Figura 8).

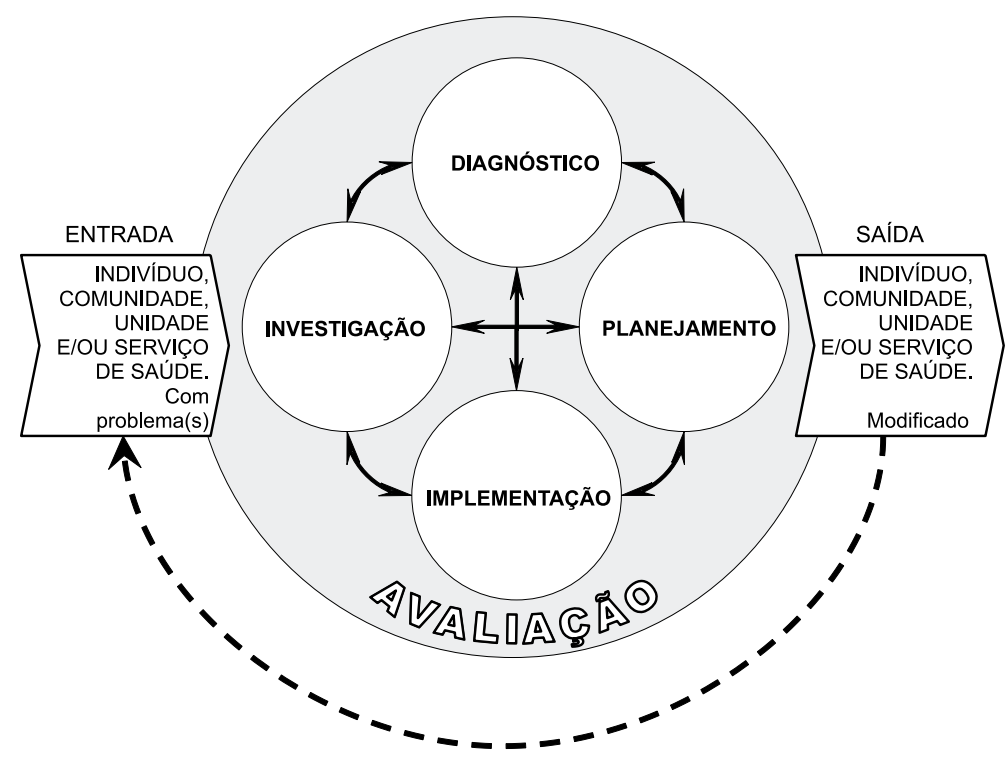

Figura 8 - O Processo de Enfermagem.

Para Daniel (1987:83), o Processo de Enfermagem

[...] não consiste somente de um modus operandis de planejamento específico e direto para o atendimento das necessidades básicas dos indivíduos mas, igualmente, de um sistema amplo e

1 "Como se encontra classificado no International Nursing Index e segundo terminologia corrente na literatura nacional" (DANIEL, 1987). 
abarcante que engloba, além do estudo do plano assistencial, a situação contextual geral onde esse será desenvolvido.

$\mathrm{O}$ profissional enfermeiro, no que se refere às suas funçóes gerenciais, pode estar presente nos três níveis organizacionais descritos por Parsons apud Chiavenato (2000), ou seja, no Nível Estratégico, no Nível Intermediário e no Nível Operacional.

Conforme a descrição destes níveis organizacionais, um enfermeiro que se encontra no nível operacional não poderia exercer o gerenciamento clínico em Enfermagem, tampouco aplicar o enfoque Estratégico Situacional no planejamento das ações de Enfermagem.

O enfermeiro que exerce a função assistencial, não só executa as tarefas, mas, planeja a execução destas tarefas, exercendo, assim, uma das funções do gerenciamento clínico em Enfermagem, o que o diferencia de qualquer outro profissional que esteja no nível operacional.

Nesse contexto, observa-se que o envolvimento do pensamento de Planejamento Estratégico Situacional é pertinente, porque este tipo de planejamento privilegia a idéia de momento através de um conjunto de técnicas, métodos, destrezas e habilidades; permite ao enfermeiro aumentar sua capacidade de direção, gerência e administração e leva-o a conhecer as reais necessidades do cliente para planejar uma assistência que venha, de fato, a beneficiá-lo.

Reforçando este pensamento, Ciampone (1991, p. 57) diz que

[...] acredita-se que a metodologia proposta possa melhor embasar as atividades de Enfermagem nos diferentes níveis de complexidade. Acredita-se também que o conhecimento das fases da metodologia do planejamento ajudará o enfermeiro a torná-lo um instrumento útil, e não apenas teórico e inaplicável. 
Nesse sentido, concordamos com a crença de que o planejamento da assistência de Enfermagem seja a função que possibilita ao enfermeiro exercer o Gerenciamento Clínico de Enfermagem de forma global, coerente e responsável.

O PES, por preencher a necessidade de se utilizar métodos racionais, analíticos e intuitivos, baseados, inclusive, na incerteza do amanhã e na criação de futuros alternativos, deve ser utilizado para evitar que as decisões administrativas se transformem em "políticas de apaga fogo" (GERDES; ERDMANN, 1995).

Considerando o disposto até aqui, com relação ao enfoque de Planejamento Estratégico Situacional, podemos afirmar que este tipo de planejamento tem muitas aplicações nos serviços de Enfermagem, inclusive no planejamento da assistência propriamente dita, aqui definida como Gerenciamento Clínico de Enfermagem, por ser considerado um forte instrumento para sistematizar o trabalho, prever mudanças e adequar os recursos, a fim de atingir os objetivos propostos.

Castilho e Gaidzinski (1991, p. 210) afirmam que:

[...] uma questão limitante na operacionalização de sistemas organizados de trabalho é a falta de estruturas organizadas em muitos serviços. Por este motivo os enfermeiros necessitam posicionar-se, propondo uma maneira de trabalho diferente, que conduza à uma forma de organização do serviço, e leve em conta as atividades inerentes à profissão, bem como o estudo crítico do atendimento que se presta.

O disposto até aqui nos leva a acreditar que, embora o Processo de Enfermagem tenha sido projetado para aplicação na assistência, ele pode ser facilmente adaptado como um modelo teórico para enfrentar problemas administrativos (MARQUIS; HUSTON, 1999).

Além disso, essas autoras identificam o Processo de Enfermagem como um sistema teórico para solucionar problemas e tomar decisões, ou seja, é um processo decisório. 
Assim o enfermeiro pode integrar o Processo Administrativo com o Processo de Enfermagem, adaptando-o à prática administrativa, para sistematizar as suas funções administrativas (Figura 9).

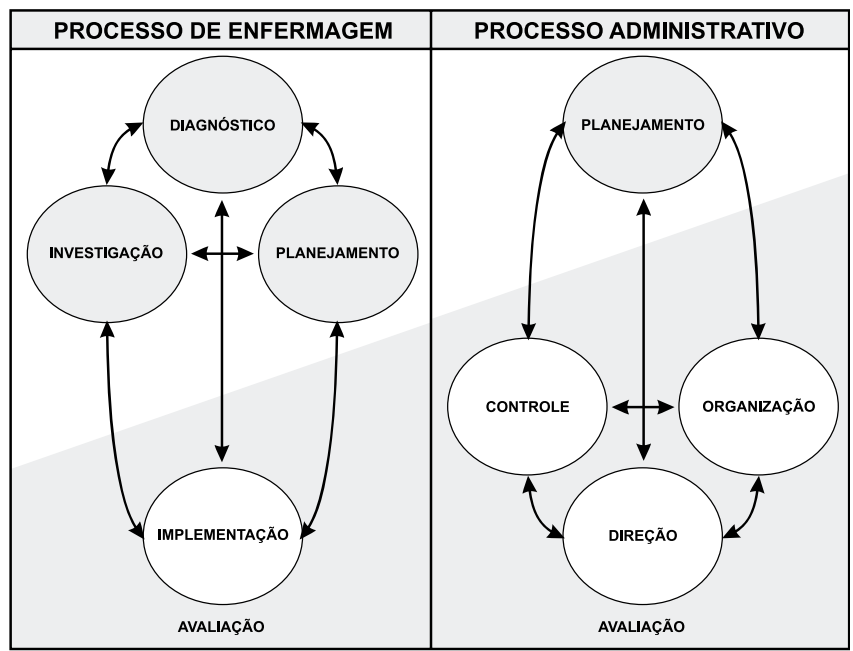

Figura 9 - Integração do Processo Administrativo com o Processo de Enfermagem.

Podemos reforçar esse pensamento, ao concordar com Tancredi et al. (1998) quando afirmam que não existe "a teoria" ou “o método" de planejamento. Há uma vasta literatura sobre planejamento; há, também, uma vasta terminologia. Uma fantasia freqüente é que exista "o método" de fazer planejamento. Todas as "teorias" e "métodos" não escapam muito da busca de definir qual o futuro desejado, isto é, aonde queremos chegar com o nosso sistema e como apontá-lo naquela direção. Muitos autores fizeram largas divagações sobre essa coisa tão simples, porque, obviamente, o jogo de forças, interesses e ideologias faz com que nem sempre seja fácil definir esse "norte" e tampouco as formas de chegar lá.

O melhor "método", segundo esses autores, é aquele que melhor ajudar numa determinada situação. 
O método CENDES/OPS, atualmente abandonado por sua baixa praticidade e seu mecanicismo, legou-nos importantes conceitos sobre custo-benefício das ações em saúde, como, por exemplo, sobre a transcendência social dos agravos à saúde. Em suma, é pouco provável que, na prática, alguém siga ipsis litteris um determinado método; é mais provável que na seqüência do trabalho vá incorporando diversos instrumentos de trabalho retirados de muitas partes (TANCREDI et al., 1998).

Dessa forma, Matus aconselha que é necessário combinar métodos distintos, conforme o nível de hierarquia e de complexidades dos problemas.

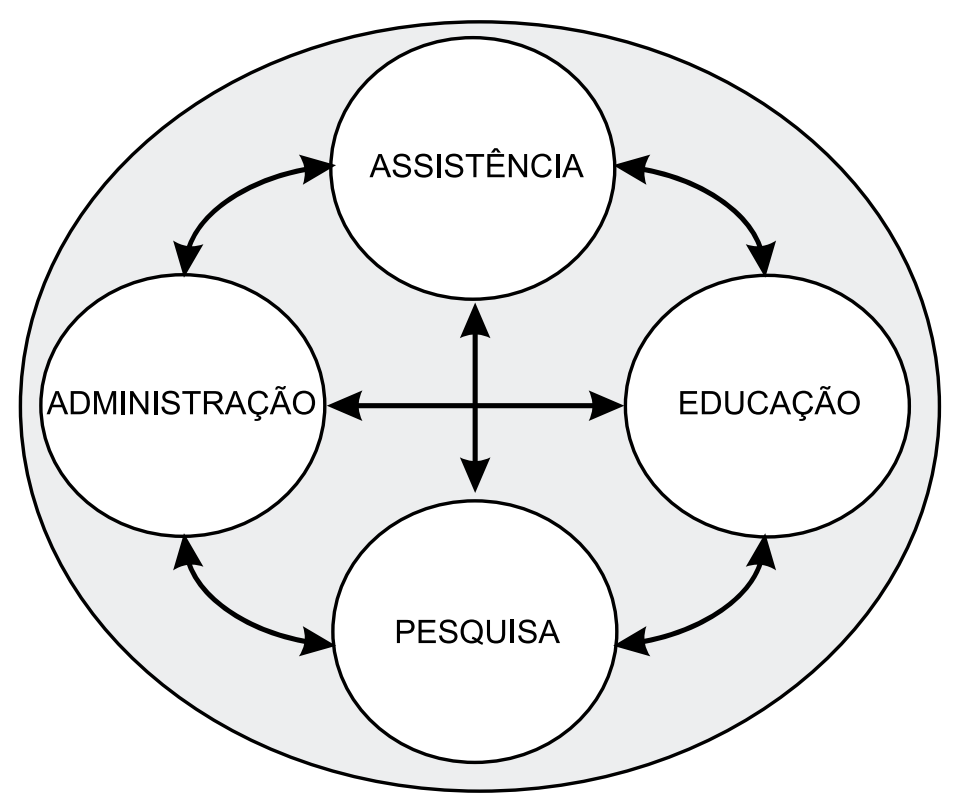

Figura 10 - Ações de Enfermagem.

Considerando essa sugestão e reconhecendo o Processo de Enfermagem como um método de planejamento das ações de Enfermagem (Figura 10), ou seja, açôes assistenciais, açôes administrativas, ações educativas e ações de pesquisa e desenvolvimento tecnológico da profissão, recomendamos, para o processo de 
Planejamento em Enfermagem, uma integração dos momentos do PES com os momentos do Processo de Enfermagem, resultando numa combinação dos princípios dos métodos de planejamento aqui expostos com a estrutura metodológica do Processo de Enfermagem (Quadro 1). Entretanto, não é utilizado o PES como alvitrado por Carlos Matus, mas um pinçamento de elementos essenciais da base conceitual proposta e adaptada à estrutura do Processo de Enfermagem.

Quadro 1 - Integração dos momentos do Processo de Enfermagem com os momentos do PES

\begin{tabular}{|l|l|}
\hline \multicolumn{2}{|c|}{ MOMENTOS } \\
\hline $\begin{array}{c}\text { PLANEJAMENTO ESTRATÉGICO } \\
\text { SITUACIONAL }\end{array}$ & \multicolumn{1}{c|}{ PROCESSO DE ENFERMAGEM } \\
\hline - Explicativo & - Investigação \\
\cline { 2 - 2 } & - Diagnóstico \\
\hline - Normativo & - Planejamento \\
\hline - Estratégico & - Implementação \\
\cline { 2 - 2 } - Tático-operacional & - Avaliação \\
\hline
\end{tabular}

Desta maneira, o processo de Planejamento em Enfermagem, como descrito nos capítulos seguintes, é organizado dentro dos cinco momentos distintos e interdependentes, identificados como investigação, diagnóstico, planejamento, implementação e avaliação (Figura 11). Vale ressaltar que a ordem apresentada é puramente didática, já que o conceito de momento aponta para a falta de linearidade seqüencial, bem como não determina um dos momentos como único deflagrador do processo. 


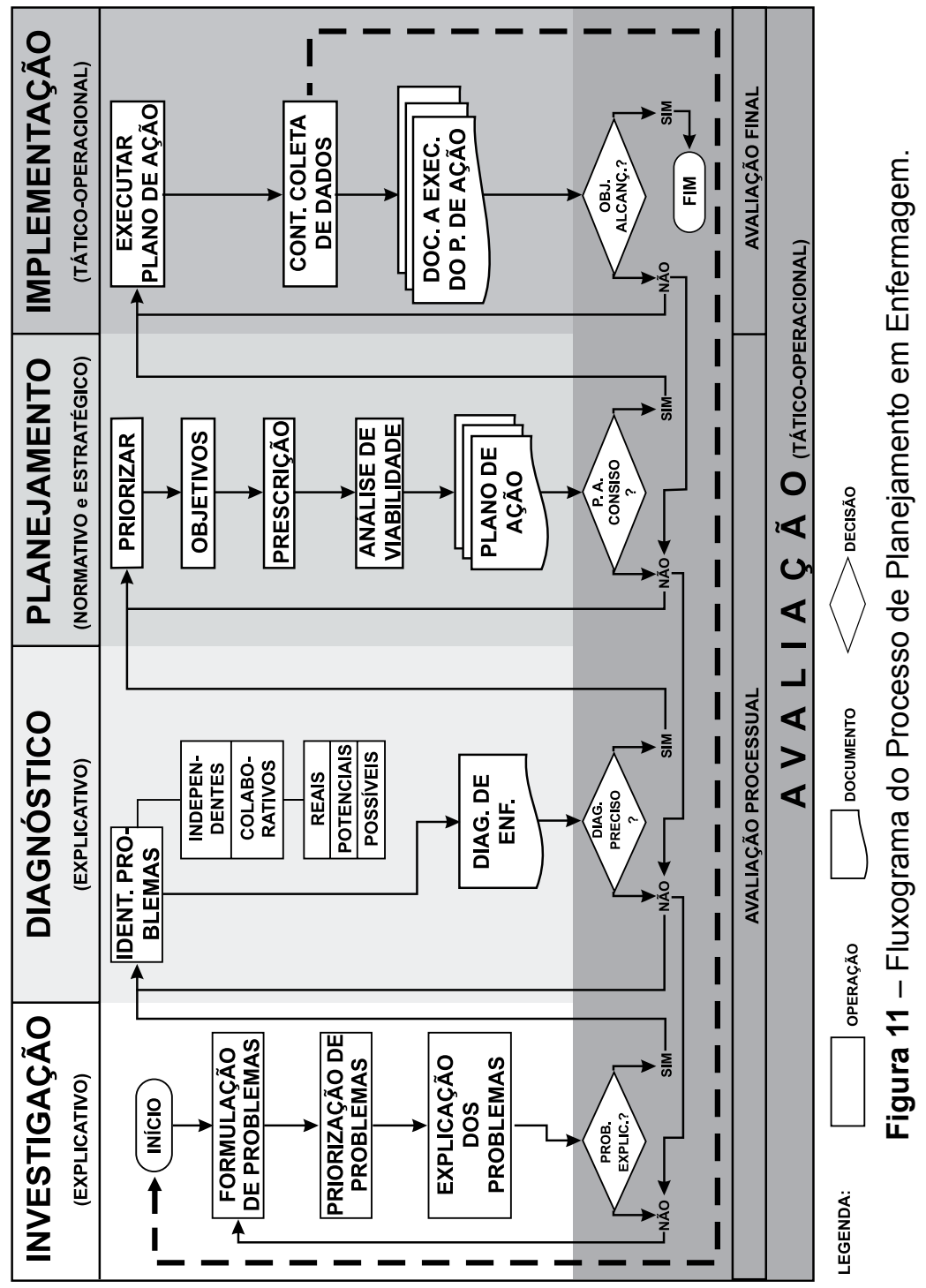




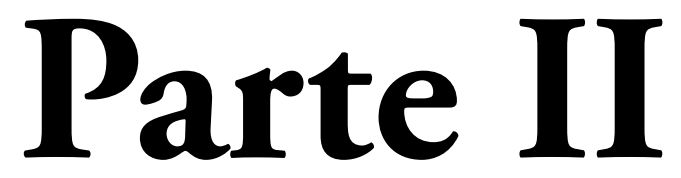

O processo de Planejamento em Enfermagem 


\section{8 \\ Algumas considerações quanto ao Processo de Enfermagem}

A intenção aqui não é fazer uma descrição do Processo de Enfermagem, já que existe uma vasta literatura a esse respeito, e sim tecer algumas considerações que subsidiarão a adaptação do Processo de Enfermagem à função administrativa exercida pelo enfermeiro, principalmente no que diz respeito às ações de planejamento realizadas pela Enfermagem. Sendo assim, e considerando o objetivo e pressuposto desse texto, é pertinente a discussão de três pontos básicos:

O primeiro ponto diz respeito à sigla SAE (Sistematização da Assistência de Enfermagem).

O Processo de Enfermagem, historicamente, tem sido utilizado para organizar e direcionar a assistência de Enfermagem, surgindo, desde então, na literatura corrente, o termo "Sistematização da Assistência de Enfermagem”, amplamente utilizado na divulgação dos avanços científicos a respeito do processo de cuidar na prática assistencial do enfermeiro.

Entende-se ser o Processo de Enfermagem uma parte essencial dessa profissão, ser uma maneira especial de pensar e agir dos enfermeiros, ser uma maneira de coordenar e resolver problemas, que oferece direção para o planejamento, implementação e 
avaliação da assistência, e envolve uma interação entre o cliente e o enfermeiro, considerando o cliente como foco principal onde, juntos utilizam o processo para tomar decisões (WILKINSON, 1992).

Além disso, diversos autores afirmam que o Processo de Enfermagem oferece um sistema teórico de resolução de problemas e tomada de decisão. E afirmam ser: um método de aplicação da abordagem científica na prática de Enfermagem (MARQUIS; HUSTON, 1999; ATKINSON; MURRAY, 1989; PAUL; REEVES, 2000); a essência da prática de Enfermagem (PAUL; REEVES, 2000; SMELTZER; BARE, 1993); o “instrumento" e a metodologia da profissão e capaz de subsidiar a previsão e avaliação das conseqüências (PAUL; REEVES, 2000); a dinâmica das ações sistematizadas e interrelacionadas (HORTA, 1979); um conjunto de etapas que devem guiar a prática de Enfermagem (SOUZA apud ROSSI; CASAGRANDE, 2001); essencial em todas as abordagens de Enfermagem (ALFARO-LEFEVRE, 2005).

Essas incursões às fontes bibliográficas, que não apontam exclusividade da aplicação do Processo de Enfermagem na prática assistencial, reconhecem que o enfermeiro, além da função assistencial, possui mais três funções básicas (administração, educação e pesquisa), leva a acreditar que o enfermeiro deve sistematizar todas as suas funções, não só a função assistencial.

Dessa forma, a sigla SAE deve significar Sistematização das “Ações” de Enfermagem através da aplicação do Processo de Enfermagem. Isto é, como a prática do enfermeiro reflete todos os seus papéis/funções, que não são isolados, mas interdependentes e muitas vezes imbricados, não existe a execução de uma função sem que haja implemento ou subsídio das outras funções. $\mathrm{O}$ Processo de Enfermagem, que surgiu na prática clínica, deve ser adaptado como um modelo teórico para utilização, também, nas práticas administrativa, educativa e de pesquisa. 
O segundo ponto, partindo de uma visão sistêmica e contingencial, faz enxergar que o Processo de Enfermagem deve refletir a essência do pensamento sistêmico. Essa essência, para Maximiano (2000), consiste na idéia de elementos que interagem e formam conjuntos para alcançar objetivos; reconhece a realidade como constituída de sistemas, que são feitos de elementos interdependentes, e, para compreender a realidade, é preciso analisar as interrelações dos elementos que a compõem. Chiavenato (2000) acrescenta que os sistemas apresentam relações de intercâmbio ambiental, onde ambiente representa o contexto que envolve a organização e a situação dentro da qual esta organização está inserida.

A visão sistêmico/contingencial aponta que a tecnologia e a sociedade tornaram-se tão complexas que as soluções tradicionais já não são suficientes. Torna-se necessário, então, utilizar abordagens de natureza holística ou sistêmica, generalista ou interdisciplinar. Portanto, juntamente com a teoria contingencial, que salienta não existir uma única melhor forma de organizar o alcance dos objetivos, a teoria dos sistemas é a reorientação do pensamento e da visão do mundo a partir da introdução dos sistemas como um novo paradigma científico, que contrasta com o paradigma analítico, mecanicista e linear de causa e efeito, da ciência clássica (MAXIMIANO, 2000; CHIAVENATO, 2000).

Dessa forma, o Processo de Enfermagem (Figura 8), como qualquer sistema, é representado como um conjunto de elementos ou componentes que se organizam em três partes: entradas, constituídas por: indivíduo, comunidade, unidade e/ou serviço de saúde etc. com problemas de saúde; processos, representado pela execução das ações sistematizadas de Enfermagem; e saídas, formadas pelo indivíduo, comunidade, unidade e/ou serviço de saúde etc. modificado (sadio ou melhorado).

O terceiro ponto a ser considerado reside no fato de o Processo de Enfermagem ter sido habitualmente descrito como 
composto por fases ou etapas. Isto vem acontecendo, talvez, em função do sentido atribuído à palavra "processo", que remonta aos sentidos de etapas ou fases seqüenciais, bem como à impregnação do pensamento cartesiano/racionalista, e do taylorismo e fordismo, ainda existentes na Enfermagem.

Contrapondo a acepção de fases ou etapas, característico do planejamento normativo, é pertinente considerar o Processo de Enfermagem como composto por "momentos", no sentido matusiano do termo.

Matus (1993, p. 297) considera que o termo momento sugere "instância, ocasião, circunstância ou conjuntura pela qual passa um processo contínuo, ou em cadeia, que não tem começo nem fim definidos". Dessa forma, segundo este autor, nenhum momento começa ou termina no tempo preciso, nem é necessariamente anterior ao outro, nem fecha ou termina o processo encadeado, bem como, não fica definitivamente para trás, nem se esgota numa só instância, voltando a se repetir outras vezes para, no futuro, transitoriamente dominar.

Para Matus (1993), os momentos são repetitivos, ou cíclicos, estando todos sempre presentes na situação e, dentro do Processo de Enfermagem, esses momentos encadeiam-se e compõem circuitos cíclicos capazes de se amparar reciprocamente e passar sempre a um outro momento distinto. A passagem das açóes de Enfermagem por um momento determinado é apenas o domínio transitório deste momento sobre ou outros, que sempre estão presentes.

Parafraseando Matus (1993, p. 300), compreendemos que a coleta de dados no momento da investigação, no Processo de Enfermagem, é uma atividade que não cessa nunca, mesmo que ela se repita com diferentes conteúdos, propósitos, datas, ênfases e em diferentes contextos situacionais. Ocorre o mesmo com o momento do diagnóstico, do planejamento, da implementação e da avaliação. O plano de ação ou de cuidados está sempre pronto 
e sempre sendo feito. Só o conceito de momento permite compreender o significado desta frase aparentemente contraditória.

$\mathrm{Na}$ Enfermagem, seja em qualquer das funçôes exercidas pelo enfermeiro, é comum o profissional identificar um proble$\mathrm{ma}$, sem conhecer imediatamente os seus microproblemas (causas e consequiências). A identificação do problema, individual ou coletivamente, é uma ação descrita no Processo de Enfermagem como sendo do momento do diagnóstico (segundo momento). Para conhecer os microproblemas, é necessário ir para o momento de investigação (primeiro momento), e a partir daí dar continuidade às açôes dentro do restante do processo.

Nesse caso, o Processo de Enfermagem foi deflagrado no momento do diagnóstico, didaticamente apontado como segundo momento do processo, passando para o momento de investigação, didaticamente apontado como primeiro momento do processo, para, em seguida, de posse das informaçōes sobre as causas e conseqüências, retornar para o momento de diagnóstico e assim conseguir fazer as declarações diagnósticas, e percorrer os outros momentos. Ficando evidente que qualquer momento do Processo de Enfermagem pode desencadear e finalizar o processo. 


\section{9 \\ Bases conceituais e metodológicas}

Do mesmo modo que no capítulo anterior, a intenção não é fazer uma descrição das bases conceituais e metodológicas para o processo de Planejamento em Enfermagem, e sim trançar alguns comentários complementares que ajudarão nesse processo.

Entre as vertentes de planejamento em saúde, destaca-se o Planejamento Estratégico Situacional (PES), mais precisamente a chamada trilogia matusiana, por favorecer a operacionalização do método através da conjugação de três métodos: o próprio PES, o ZOPP (Planejamento por Projetos Orientado por Objetivos) e o MAPP (Método Altadir de Planejamento Popular) desenhados, respectivamente, para os níveis institucional/central, intermediário e operacional/local, ou seja, a trilogia matusiana pode ser utilizada nos distintos níveis gerenciais de uma organização ou em organizações de diferentes complexidades (ARTMANN, 2000; SILVA, 1994).

$\mathrm{O}$ enfoque estratégico instrumentaliza a gestão para o enfrentamento de problemas, possibilitando a participação efetiva dos atores sociais no processo, explicando o problema a partir a visão do ator que o declara, bem como identifica as possíveis causas e busca diferentes maneiras de abordar ou propor soluções para o mesmo. Tem como objeto de planejamento os problemas e oportunidades reais de intervenção, em uma perspectiva que 
supera a fragmentação reducionista da realidade operada pelas disciplinas cartesianas no setor de saúde (TEIXEIRA, 2001).

Nessa perspectiva, problema de saúde pode ser compreendido, segundo Vilasboas e Teixeira (1999, sp), como

[...] qualquer acontecimento considerado fora dos padrões de normalidade para quem está analisando uma determinada situação. Assim, pode ser uma doença, um agravo, uma insuficiência de recursos ou uma ausência de um determinado serviço de saúde, ou até fatos que, na verdade, explicam uma doença (por exemplo, falta de saneamento básico, fome etc.).

Além disso, esse enfoque de planejamento estratégico tornou-se sinônimo de um processo de planejamento participativo voltado para as necessidades e interesses dos diversos atores sociais envolvidos em uma determinada situação (CORDIOLLI, 2001). Esta participação significa a participação no poder e representa uma construção conjunta, ou seja, não só contribuir com a proposta preparada por algumas pessoas, mas passar a ser sujeito ativo no processo.

Cordiolli (2001) ressalta que a participação não é somente um instrumento para a solução dos problemas, mas também uma necessidade do homem de auto-afirmar-se, de interagir em sociedade, criar, realizar, contribuir, sentir-se útil. A não participação dos atores implicará, em grande parte, no pouco comprometimento e pouca identificação para o enfrentamento dos problemas vivenciados. O planejamento participativo pode ser um instrumento muito eficaz para aumentar a motivação e o entusiasmo das pessoas, contribuindo para o surgimento do pleno potencial de uma organização.

Para que o planejamento participativo não sofra um desgaste, ao se tornar uma manipulação das pessoas através de um simulacro de participação e ao se utilizar de metodologias inadequadas, Gandin (1994, p. 56) propõe a verificação dos três níveis de participação: 
O primeiro nível é a colaboração, o nível mais freqüente na prática, hoje, embora não se possa chamar verdadeiramente de participação, porque é o nível em que a "autoridade" chama as pessoas para trazerem sua contribuição a fim de alcançar o que esta mesma "autoridade" decidiu como proposta. Decorre de um pensamento autoritário e normativo que, embora superado no discurso, pertence à mais clara realidade atual. Esse autor chama a atenção para o fato de que este tipo de participação tem seus pontos positivos, e é até importante, em algumas situaçōes extremas, porém o seu ponto negativo é ser entendido como o único modo de se promover a participação.

O segundo nível é chamado de nível de decisão, e vai além da colaboração, tendo uma aparência democrática mais acentuada. Aqui, o "chefe" decide que todos vão decidir. Assim, leva algumas questôes a uma assembléia, independente da dimensão da plenária, e manda que todos decidam. Em geral, são decididos aspectos menores, desconectados da proposta mais ampla, e a decisão se realiza como escolha entre alternativas já traçadas, sem afetar o que realmente importa. Esse autor esclarece que não se deve condenar estas precárias manifestaçóes democráticas, mas limitar-se a elas diminui a força transformadora do planejamento participativo.

O terceiro nível é denominado de construção em conjunto. Este nível acontece quando o poder está distribuído entre os atores sociais. Permite, através de um trabalho coordenado, a construção de um processo de planejamento em que todos, com seu saber próprio, com sua consciência, com sua adesão específica, organizam seus problemas, suas idéias, seus ideais, seu conhecimento da realidade, suas propostas e suas açóes.

O planejamento participativo exige uma disponibilidade e um interesse em se envolver numa ação comunicativa, buscando o envolvimento dos atores em um trabalho coletivo em defesa da saúde. Numa visão estratégica, pode ser entendida como uma 
clareza sobre o que é necessário e possível ser feito (VILASBOAS; TEIXEIRA, 1999) e um agir estratégico, tendo como foco o tornar possível, no futuro, o que hoje parece impossível e manter atenção sobre o que é mais importante fazer para atingir os objetivos traçados, ou seja, planejar para construir viabilidade. 


\section{0 \\ Momento de investigação}

Quando se realiza busca ativa de problemas, a investigação torna-se o primeiro momento do processo de planejamento. Por outro lado, quando os problemas são detectados espontaneamente, na dinâmica do trabalho diário, em oficinas, em reunióes etc., a investigação é iniciada após o momento inacabado de diagnóstico. Inacabado porque é necessário o levantamento das causas e consequiências (evidências) para concluir a Declaração Diagnóstica.

Em relação ao Planejamento Estratégico Situacional, a investigação corresponde ao Momento Explicativo. Suas atividades são concentradas em reunir informações para a explicação do problema. Inicia-se com a elaboração de uma listagem de problemas para, seqüencialmente, identificar o problema nuclear (macroproblema) e relacionar as suas causas e conseqüências (microproblemas).

As informaçôes podem ser obtidas através de várias técnicas de coleta de dados, tais como: consulta a documentos diversos (relatórios profissionais, relatórios de pesquisa etc.), questionários, entrevistas e sessões em grupo (tais como oficina, grupo focal e brainstorming). Pena (2004) salienta que, seguindo os princípios do planejamento estratégico, deve ser valorizada a utilização de técnicas informais, que privilegiem a flexibilidade e a criatividade, como a entrevista não estruturada, o grupo-focal e brainstorming. 
As entrevistas não estruturadas, podendo ser representadas pelas conversas informais entre os atores situacionais, não limitam a criatividade e abrangência da informação a ser recolhida e podem complementar a informação recolhida através do brainstorming e do grupo-focal (PENA, 2004).

O grupo focal é uma técnica qualitativa, não-diretiva, que utiliza um pequeno grupo de discussão informal (máximo de 12 pessoas), com o propósito de obter informaçóes em profundidade, cujo resultado visa ao controle da discussão de um grupo de pessoas. Nesta técnica, o mais importante é a interação que se estabelece entre os participantes. O facilitador da discussão deve estabelecer e facilitar a discussão e não realizar uma entrevista em grupo (TANAKA; MELO, 2001).

Santos e Moura (2000) informam que essa técnica tem como objetivo principal a revelação das percepções dos participantes sobre os tópicos colocados em discussão. Tem como vantagens o custo relativamente baixo, a rapidez na execução, a interação forte com os elementos de informação e a profundidade de informações. Como limitaçôes, podemos apontar que é susceptível ao viés do ponto de vista do moderador e as discussões podem ser desviadas ou dominadas por algum participante.

O brainstorming também conhecido como "Tempestade Cerebral", "Tempestade de Idéias" ou simplesmente "Coleta de Idéias" é uma técnica usada para ajudar a criar o máximo de idéias possíveis em curto período de tempo. O grupo para uma sessão de brainstorming também é pequeno, mesmas dimensões do grupo focal, onde as pessoas dão suas idéias e à medida que elas aparecem, são listadas. Neste momento, é mais importante a quantidade, o fluxo de idéias. O objetivo é que uma palavra ou idéia "complemente" a outra. As idéias devem ser escritas com as mesmas palavras utilizadas pela pessoa, não devendo ser interpretadas. Esta prática proporciona o 
entusiasmo do grupo, o envolvimento de todos e, normalmente, resulta em soluções originais para os problemas (ARIOLI, 1998).

\subsection{Formulação de problemas}

Quando o processo de planejamento é iniciado pelo momento de diagnóstico, provavelmente já existe uma relação prévia de problemas que pode ser expandida e reformulada no momento de investigação. Quando o processo é deflagrado pelo momento de investigação, recomenda-se a utilização de trabalhos em grupos.

Para Matus (1993), o problema deve ser declarado pelos atores a partir de sua identificação no espaço situacional. A diferença entre um problema e um simples incômodo é a capacidade de explicá-lo. O problema é explicado seguindo um conjunto de descritores que tornam a explicação do problema única, clara e objetiva para todos os atores envolvidos, respondendo: O que é? Quem é atingido? Onde ocorre? Quando ocorre? Esse conjunto de descritores é denominado por Matus como Vetor de Descrição do Problema (VDP).

Pena (2004) alerta para a possível ocorrência de equívocos na formulação dos problemas, podendo aparecer descrições de problemas que são somente juízos de valor, suposiçōes, interesses pessoais, culpabilizações etc. e sugere critérios e regras para considerar um problema de fato, servindo como mecanismo para disciplinar o raciocínio. Como critérios, entende que o problema deve ser concreto e sustentável, e como regras, afirma que o problema deve ser expresso na negativa e estar formulado de forma sintética. Os critérios e as regras sugeridos por este autor são descritos a seguir: 


\subsubsection{Critérios para considerar um problema:}

1. O problema deve ser concreto. O problema deve ser racional, e não personificado, não levantando suspeitas sobre pessoas. Dessa forma ocorre a focalização da atenção dos participantes nas soluções e não nos "culpados".

Por exemplo: "falta de profissionalismo do responsável pelo posto de Enfermagem" - situação apresentada de forma personificada, sendo difícil partilhar este problema com o responsável pelo posto, correndo o risco deste boicotar a intervenção. Melhor seria: "demora no atendimento telefônico" e/ou "demora no encaminhamento das solicitações de exames aos devidos setores".

2. O problema deve ser sustentado. Deve ser significativo para o funcionamento do campo onde ocorre a intervenção, ou seja, quando são levantados problemas que, no espaço-tempo em que decorre a intervenção, não têm impacto significativo no contexto, não devem ser considerados.

Por exemplo: O problema "demora no encaminhamento das solicitaçóes de exames aos devidos setores" aconteceu apenas uma vez em um ano, e ficou retido na memória de um ator participante da dinâmica de grupo, não deve ser considerado na lista de problemas. No entanto, deve ser discutido, no sentido de se verificar a incidência desse fato.

\subsubsection{Regras para formular um problema}

1. O problema deve estar formulado na negativa. A situação problema deve ser formulada como sendo passível de melhoria, isto é, na negativa (expressão negativa).

Por exemplo: "absentismo do pessoal". Esta formulação aparentemente está na negativa. O que não é verdade, pois "a redução do absentismo" é a situação desejada (objetivo), devendo 
o problema ser formulado como "excesso de absentismo". Caso contrário a situação desejada seria o "desaparecimento do absentismo", que é uma hipótese irreal. A situação desejada deve ser sempre possível de alcançar e a formulação do problema deve levar isso em consideração (PENA, 2004, p. 15).

\section{O problema deve estar formulado de forma sintética.}

$\mathrm{Na}$ formulação dos problemas deve ser feito um esforço de síntese, para facilitar sua visualização na Árvore de Problemas ou no Fluxograma Situacional, mesmo que, posteriormente, sejam necessárias explicações para melhor contextualizar o conteúdo da formulação de um determinado problema, e para não se cometer o erro de formular dois problemas num só.

Por exemplo: $\mathrm{Na}$ formulação "demora no encaminhamento das solicitaçōes de exames aos devidos setores devido a falhas na emissão das solicitaçōes" comete-se o erro de formular dois problemas num só. $\mathrm{Na}$ realidade, estão em causa dois problemas: "demora no encaminhamento das solicitaçōes de exames aos devidos setores" e "falhas na emissão das solicitações". Ao fazer um esforço de síntese, este erro pode ser detectado.

\subsection{Priorização dos problemas}

Atendendo às proposiçóes da trilogia matusiana, pode-se empregar a metodologia utilizada no Planejamento e Programação Local de Saúde (PPLS) (VILASBOAS; TEIXEIRA, 1999). Adota-se a técnica utilizada para os Problemas da Unidade de Saúde (Figura 12), onde é indicada a utilização dos critérios RUF (Relevância, Urgência e Factibilidade), que foram inspirados em técnicas de gestão de qualidade total, mais especificamente na Matriz GUT (Gravidade, Urgência e Tendência). Adota-se, também, a técnica utilizada para os Problemas do Estado de Saúde da População (Figura 13), que é extraída do Método CENDES/OPS (desenvolvido em 1965). 
Vilasboas e Teixeira $(1999$, sp) ressaltam que "a pontuação atribuída a cada critério depende do tipo de conhecimento e da capacidade de intervenção de cada participante do processo de planejamento". Dessa forma, a priorização dos problemas diagnosticados será o resultado do consenso razoável entre os atores sociais. É muito importante ressaltar que esse método pode ser aproveitado no Momento de Investigação como técnica para priorização dos problemas a serem explicados.

\subsubsection{Problemas da Unidade de Saúde}

Conforme apresentado por Vilasboas e Teixeira (1999), o formulário destinado à priorização de problemas da unidade de saúde (Figura 12) possui três critérios, que devem receber uma pontuação específica. Os critérios são:

- Relevância do Problema - grau de importância do problema.

- Urgência - prazo para enfrentar o problema.

- Factibilidade - disponibilidade de recursos materiais, humanos, físicos, financeiros, políticos, organizativos, técnicos (conhecimentos) etc.

A pontuação atribuída, que deve ser obtida por consenso, segue um valor de 5 a 1 , do mais importante para o menos importante (Quadro 2). O valor total obtido define a ordem de prioridade. 


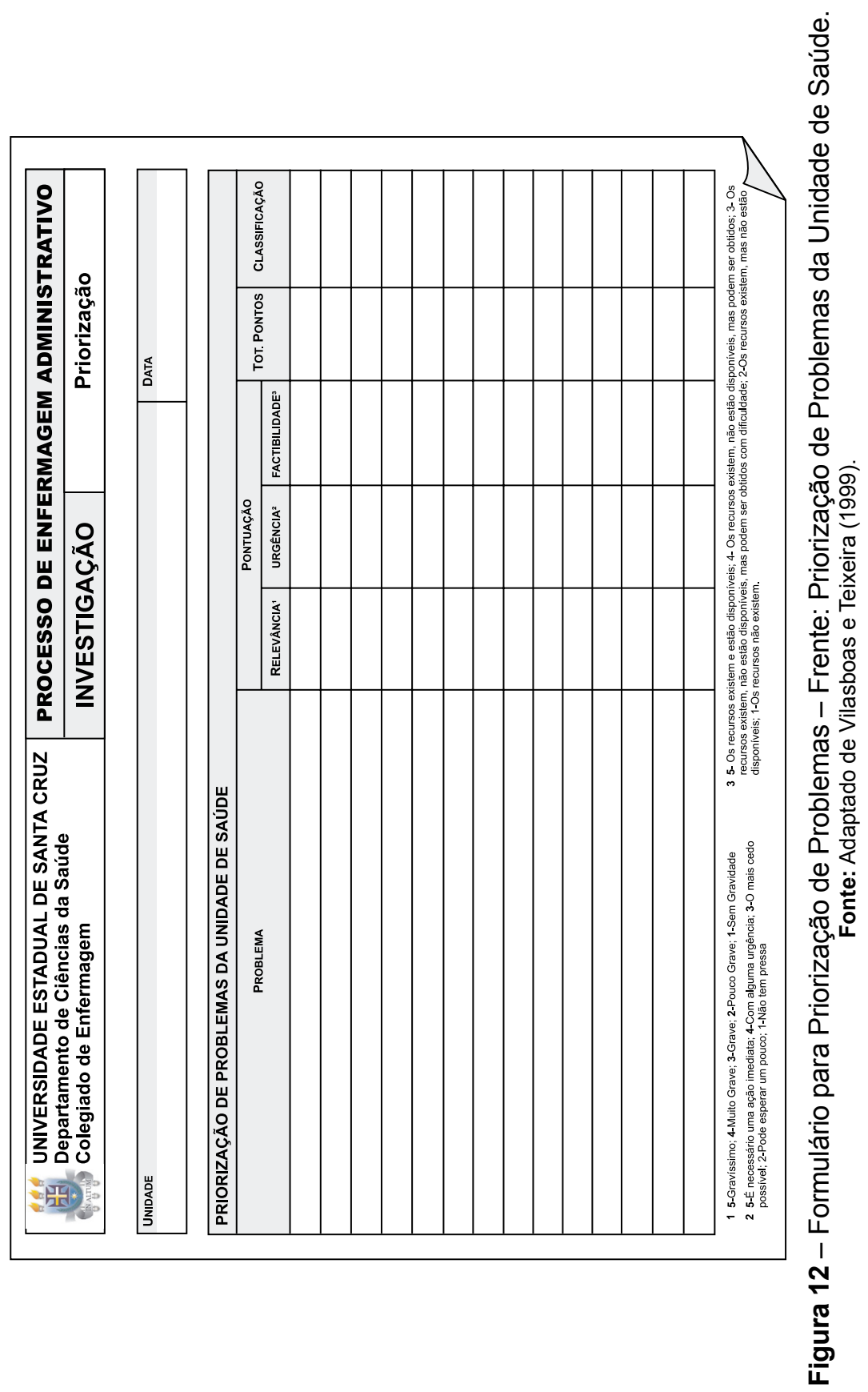


10.2.2 Problemas do estado de saúde da população

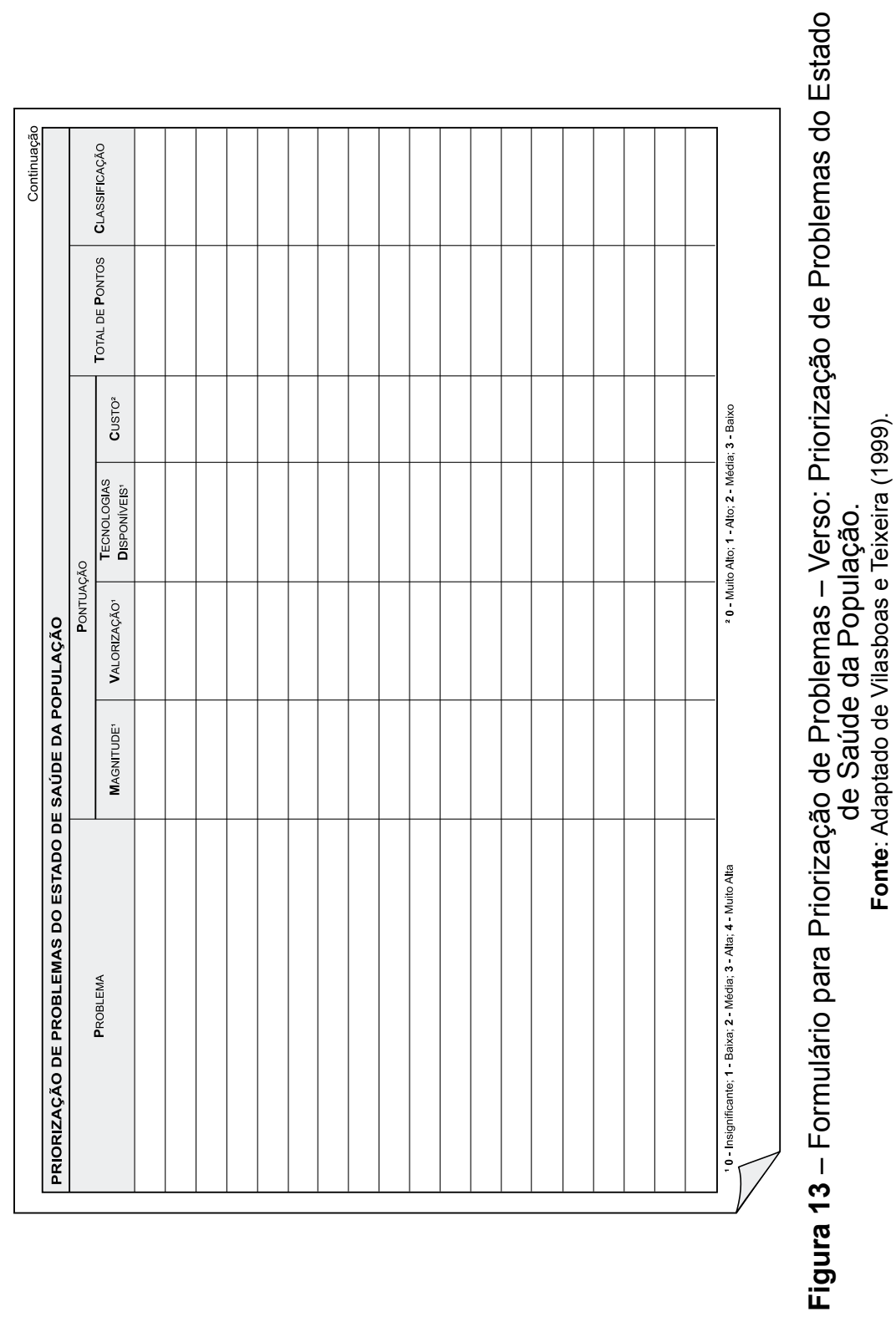


O formulário destinado à priorização de problemas do estado de saúde da população (Figura 13) possui os seguintes critérios, que deve receber uma pontuação específica (Quadro 3):

Magnitude ou tamanho do problema - geralmente refere-se ao número de casos ou de mortes relacionadas com o problema analisado (pontuação de 0 a 4);

- Valorização - importância política, cultural e técnica que é dada ao problema considerado (pontuação de 0 a 4);

- Disponibilidade de tecnologia - existência de conhecimento e recursos materiais para enfrentar o problema. Esses recursos podem estar ou não sob o controle da equipe (pontuação de 0 a 4);

- Custos - quantidade de recursos financeiros necessários para enfrentar o problema, considerando-se a disponibilidade de tecnologia analisada anteriormente (pontuação de 0 a 3).

Quadro 2 - Pontuação utilizada na priorização de Problemas da Unidade de Saúde

\begin{tabular}{|c|c|}
\hline CRITÉRIO & PONTUAÇÃO \\
\hline RELEVÂNCIA & $\begin{array}{l}5 \text { - Caso não se enfrente o problema, as conseqüências serão muito } \\
\text { graves. } \\
4 \text { - Muito graves. } \\
3 \text { - Graves. } \\
2 \text { - Pouco graves. } \\
1 \text { - Sem gravidade. }\end{array}$ \\
\hline URGÊNCIA & $\begin{array}{l}5 \text { - É necessária uma ação imediata. } \\
4 \text { - Com alguma urgência. } \\
3 \text { - O mais cedo possível. } \\
2 \text { - Pode esperar um pouco. } \\
1 \text { - Não tem pressa. }\end{array}$ \\
\hline FACTBILIDADE & $\begin{array}{l}5 \text { - Os recursos existem e estão disponíveis. } \\
4 \text { - Os recursos existem, não estão disponíveis, mas podem ser } \\
\text { obtidos. } \\
3 \text { - Os recursos existem, não estão disponíveis, mas podem ser } \\
\text { obtidos com dificuldade. } \\
2 \text { - Os recursos existem, mas não estão disponíveis. } \\
1 \text { - Os recursos não existem. }\end{array}$ \\
\hline
\end{tabular}


Quadro 3 - Pontuação utilizada na priorização de Problemas do Estado de Saúde da População

\begin{tabular}{|l|l|}
\hline \multicolumn{1}{|c|}{ CRITÉRIO } & \multicolumn{1}{c|}{ PONTUAÇÃO } \\
\hline MAGNITUDE & $\mathbf{0}$ - Insignificante \\
\hline VALORIZAÇÃO & $\mathbf{-}$ - Baixa \\
\hline TECNOLOGIAS DISPONÍVEIS & $\mathbf{2}$ - Média \\
\hline & $\mathbf{3}$ - Alta \\
& $\mathbf{4}$ - Muito alta \\
\hline \multirow{2}{*}{ CUSTO } & $\mathbf{0}$ - Muito alto \\
& $\mathbf{1}$ - Alto \\
& $\mathbf{2}$ - Médio \\
& $\mathbf{3}$ - Baixo \\
\hline
\end{tabular}

\subsection{Explicação dos problemas}

Após a formulação dos problemas de saúde, o passo seguinte é a sua explicação. Explicar um problema ou uma situação é construir um modelo explicativo de sua geração e tendências, causas e conseqüências.

No PES é utilizado o fluxograma situacional (Figura 14), onde as causas são identificadas e diferenciadas entre fluxos, acumulaçōes ou regras. Segundo Tancredi et al. (1998), os fluxos (fenoprodução) são as causas que representam ações (fatos concretos); as acumulaçóoes (fenoestruturas) referem-se às causas com caráter cognitivo (capacidades e incapacidades - valores, ideologias, teorias, predisposições, destrezas etc.); e as regras (genoestruturas) representam as leis e normas formais ou informais.

Conforme Tancredi et al. (1998), dentro do fluxograma situacional cada causa é denominada nó explicativo, no entanto, alguns nós explicativos são considerados nós críticos. Estes, por sua vez, representam as causas diretas, principais, essenciais ou cruciais do problema central (macroproblemas) e são influenciadas ou condicionadas por outras causas consideradas indiretas ao macroproblema, ou seja, quando um nó crítico é transformado em meta/objetivo alcançado, promove alteração de outra ou de uma série de causas. 


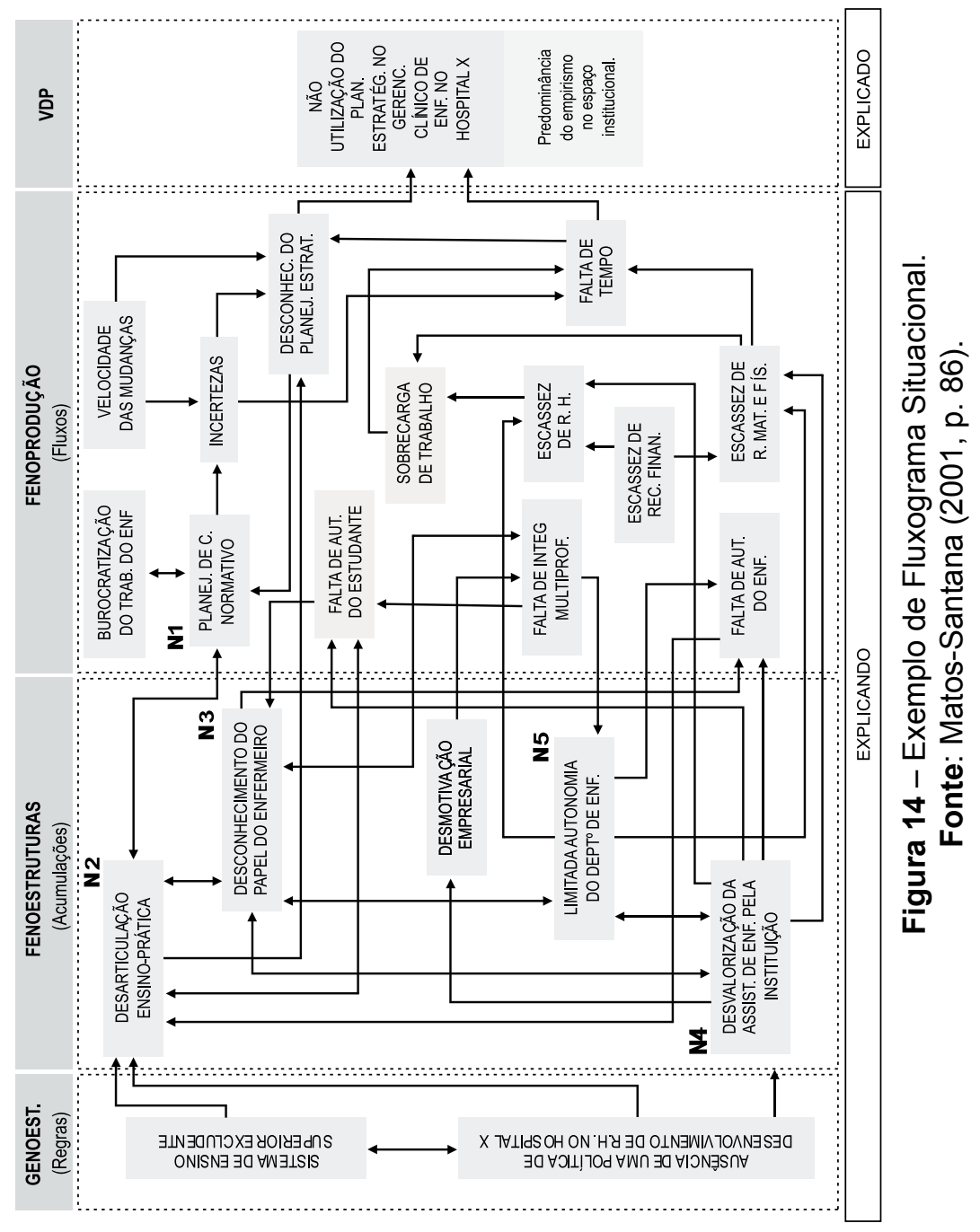


No ZOPP e no MAPP é utilizada a árvore de problemas (Figura 15), que é uma simplificação do fluxograma situacional de Matus. Essa ferramenta tem o objetivo de explicar o problema, identificando suas causas, equivalendo às suas "raízes" (determinantes) e seu "tronco" (condicionantes), bem como as conseqüências, representando os seus "galhos", "folhas", e "frutos" (fenômenos) (SÁ; ARTMANN, 1994; VILASBOAS; TEIXEIRA, 1999). Da mesma forma que no fluxograma situacional, nesse método podem ser identificados nós críticos. Podem, também, ser desenhadas árvores de problemas separadas para cada um dos problemas identificados.

Não é obrigatório que todos os atores envolvidos no levantamento de problemas participem da sua construção, mas esta deve ser partilhada e corroborada, para que seja considerada como apropriada à realidade vivenciada. Também não é aconselhável que a construção da árvore de problemas seja feita por uma só pessoa. A partilha e discussão de pontos de vista garantem as relaçóes de causalidade entre os problemas (PENA, 2004).

Para facilitar a aprendizagem da construção da árvore de problemas convém adotar uma terminologia específica, tendo como base a sugerida por Pena (2004):

Problema Central: É o macroproblema. Aquele que resulta da existência de todos os outros. Inicialmente aparece representado na parte superior da árvore, quando colocadas as causas, para, em seguida, permanecer na parte central da árvore, após a colocação das conseqüências.

Causas de $1^{\circ}$ Nível: Ou imediatas. São os microproblemas que contribuem diretamente para a existência do problema central.

Causas de 20 Nível: Ou mediatas. São os microproblemas que contribuem para os de $1^{\circ}$ nível (e assim sucessivamente, $3^{\circ}$ nível, $4^{\circ}$ nível etc.). 


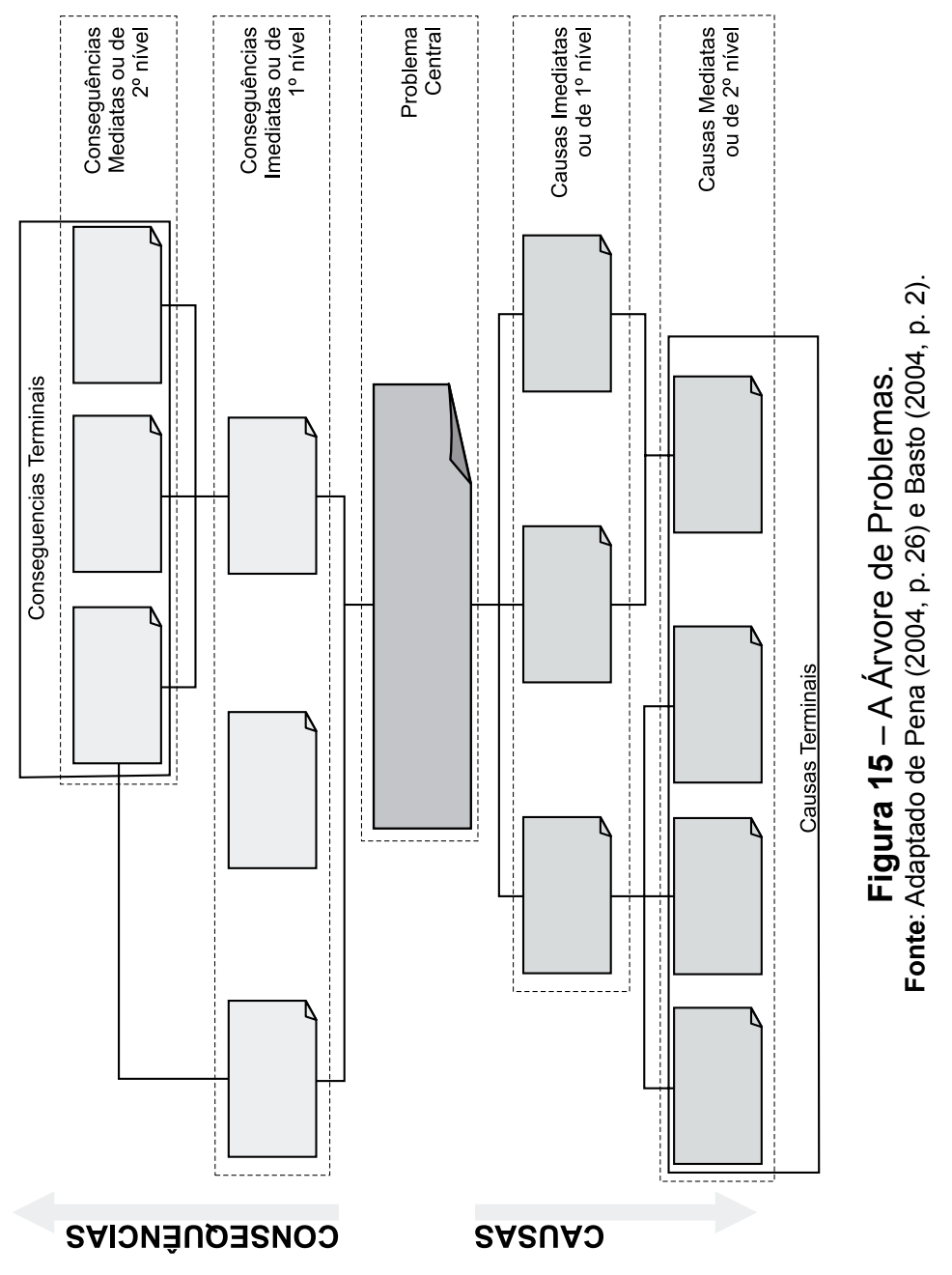


Causas Terminais: São os microproblemas que aparecem na árvore sem outras causas que contribuam para a sua existência (são as causas de raiz).

Conseqüências de $1^{\circ}$ Nível: Ou imediatos. São os microproblemas resultantes diretamente dos efeitos do problema central.

Conseqüências de 2० Nível: Ou mediatos. São os microproblemas resultantes diretamente dos de $1^{\circ}$ nível (e assim sucessivamente, $3^{\circ}$ nível, $4^{\circ}$ nível etc.).

Conseqüências Terminais: São os microproblemas que aparecem na árvore sem resultar em outras conseqüências.

Na seqüência, com base no texto de Basto (2004), é apresentado o processo de construção da árvore de problemas:

Identifica-se as causas do problema principal perguntando: "Mas, por quê?" até que não seja possível ir mais adiante. Nessa árvore as causas principais e imediatas do problema central são dispostas paralelamente por baixo do problema central, uma ao lado das outras (Figura 16).

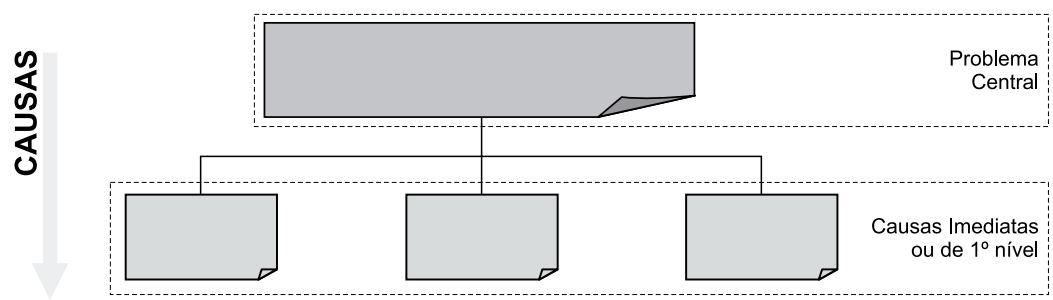

Figura 16 - Construção da rede causal da Árvore de Problemas Causas Imediatas.

Fonte: Adaptado de Pena (2004, p. 26) e Basto (2004, p. 2).

Deve-se continuar a desenvolver a análise das causas seguindo o mesmo princípio, de maneira a formar cadeias de vários níveis e ramificações (Figura 17). 


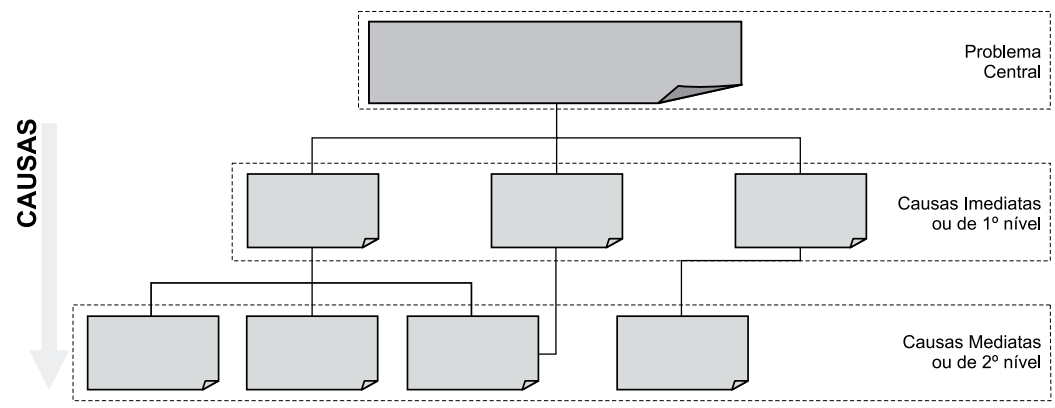

Causas Terminais

Figura 17 - Construção da rede causal da Árvore de Problemas Causas Mediatas até Terminais.

Fonte: Adaptado de Pena (2004, p. 26) e Basto (2004, p. 2).

Seguindo o mesmo raciocínio para a rede de causas, as conseqüências principais e imediatas do problema central são colocadas paralelamente, por cima do problema central, umas ao lado dos outras (Figura 18).
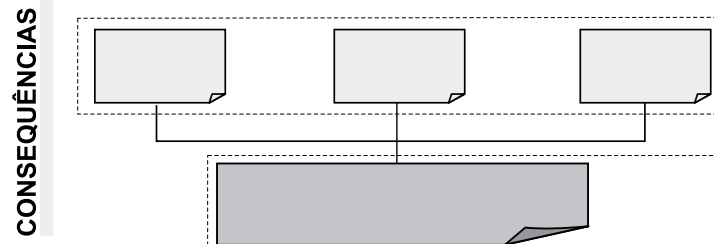

Conseguências Imediatas ou de $1^{\circ}$ nível
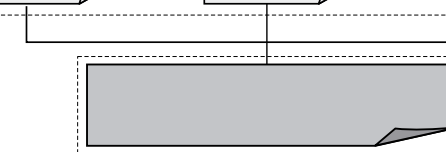

Problema Central

Figura 18 - Construção da rede de conseqüências da Árvore de Problemas - Conseqüências Imediatas.

Fonte: Adaptado de Pena (2004, p. 26) e Basto (2004, p. 2).

Da mesma forma, deve-se continuar a desenvolver a análise das conseqüências segundo o mesmo princípio, de maneira a formar cadeias de vários níveis e com ramificaçôes (Figura 19). 


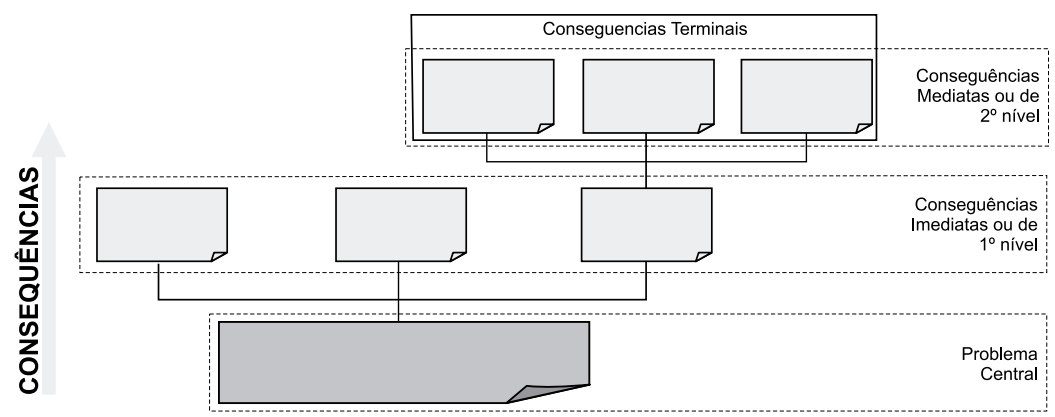

Figura 19 - Construção da rede de conseqüências da Árvore de Problemas - Conseqüências Mediatas até Terminais. Fonte: Adaptado de Pena (2004, p. 26) e Basto (2004, p. 2).

É importante conferir a árvore de problemas para garantir que cada problema conduza ao próximo, de forma lógica. Para ajudar sua montagem, sugere-se a utilização do formulário demonstrado na Figura 20.

A construção dessa árvore, adverte Pena (2004), pressupóe que a intervenção é feita num contexto complexo, onde as variáveis que o afetam nem sempre são controláveis e outras são imperceptíveis, sendo necessário captar uma ferramenta que permita sintetizar, reduzir a complexidade do contexto e permita a discussão e a procura do consenso. No entanto, essa metodologia é uma ferramenta reducionista da realidade ao estabelecer relações de causa-efeito, devendo haver consciência desse fato e de que essas relações são na realidade sistêmicas e complexas. 


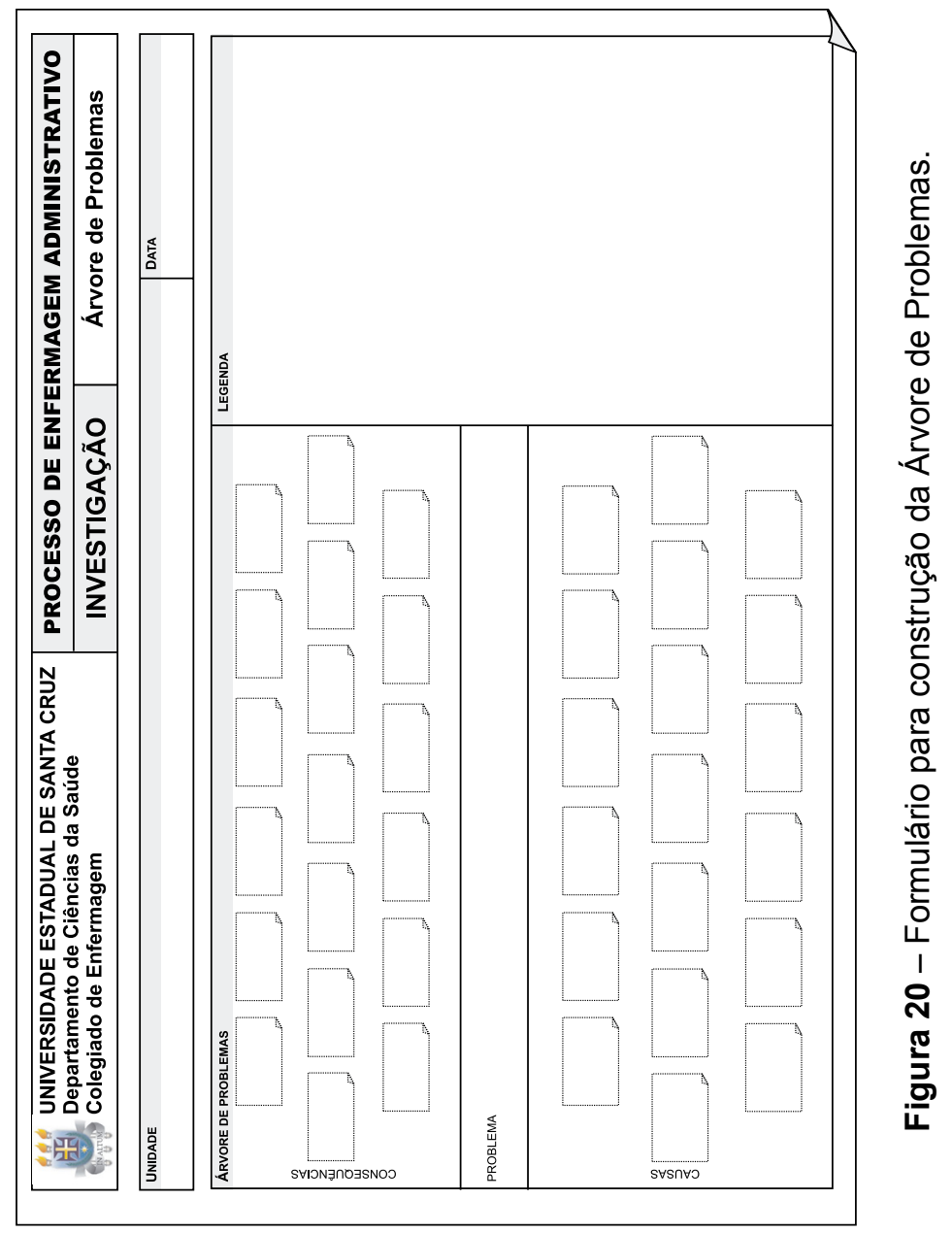




\section{1 \\ Momento de diagnóstico}

Continuando no Momento Explicativo do PES, conforme demonstrado no Quadro 1, o momento de diagnóstico do Processo de Enfermagem tem como atividade principal a construção dos diagnósticos de Enfermagem, iniciado com a identificação dos tipos problemas (diagnósticos de Enfermagem e problemas colaborativos) e dos estados dos problemas (reais, potenciais e possíveis) (Figura 21), para, em seguida, fazer a(s) declaração(ões) diagnóstica(s).

É preciso lembrar que o processo de Planejamento em Enfermagem pode ser iniciado pelo momento de diagnóstico, indo ao momento de investigação para o levantamento das causas e conseqüências, fundamentais, para, retornando ao momento de diagnóstico, completar a(s) declaração(ões) diagnóstica(s). Os diagnósticos de Enfermagem fornecem um enfoque central para os outros momentos do processo.

$\mathrm{Na}$ função assistencial, o enfermeiro faz diagnósticos clínicos sobre as respostas do indivíduo, família ou comunidade aos problemas de saúde reais, potenciais ou possíveis. $\mathrm{Na}$ função administrativa, porém, os diagnósticos são sobre problemas administrativos, sejam eles diagnósticos de Enfermagem, problemas colaborativos, reais, potenciais ou possíveis. 


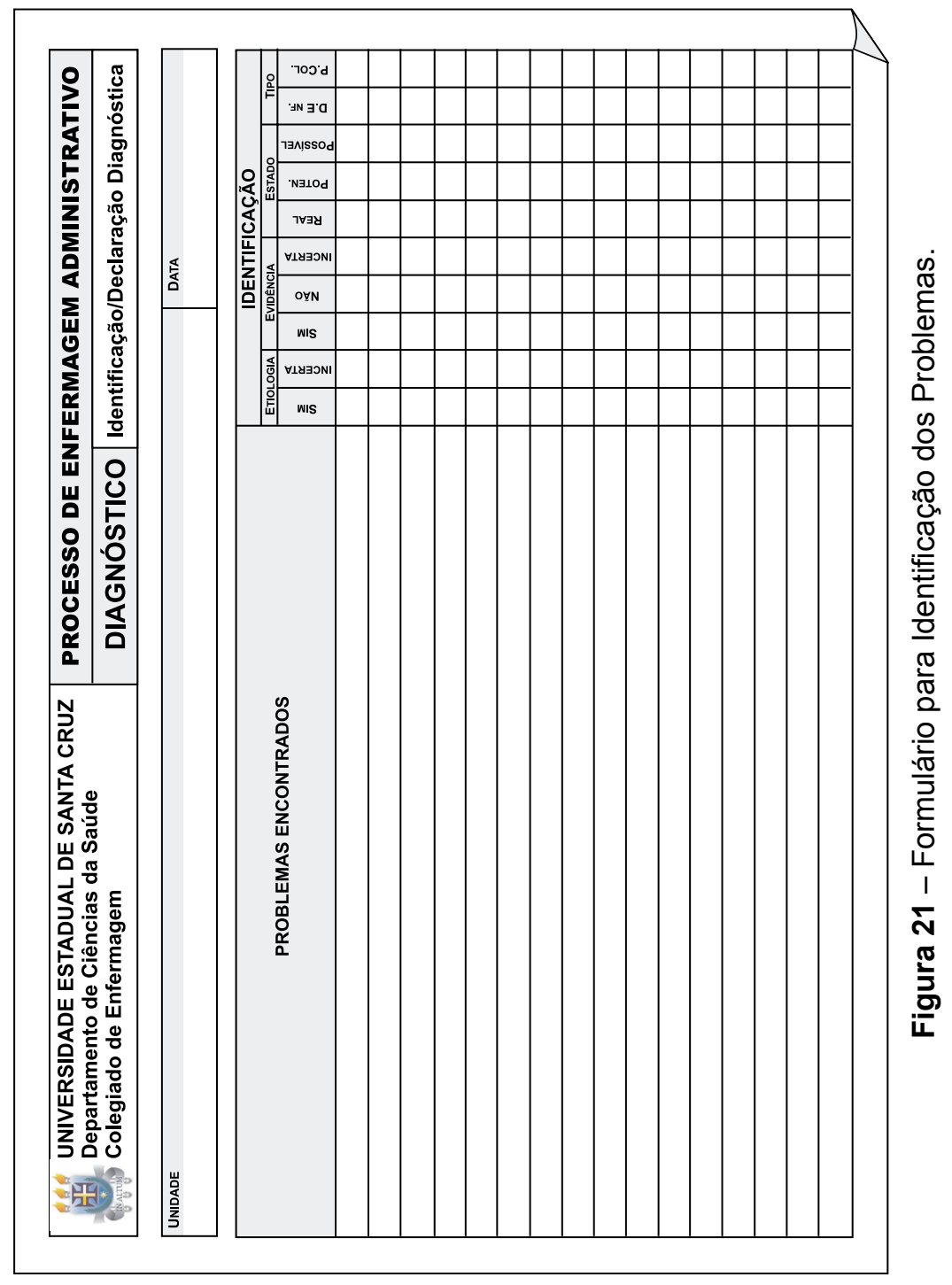


Os diagnósticos de Enfermagem dizem respeito aos problemas que a equipe de Enfermagem possa abordar de forma autônoma, sem a necessidade de intervenção de outras categorias profissionais. Por outro lado, os problemas colaborativos representam aqueles em que a equipe de Enfermagem aborda em cooperação/co-participação com outros profissionais de saúde.

Os problemas reais são definidos quando, na explicação do problema, existe a presença das causas e das conseqüências. Quando, na explicação do problema, são levantadas as causas, porém sem apresentar as conseqüências, os problemas são definidos como potenciais (ou de risco).

Por outro lado, os problemas possíveis são definidos quando as causas e as conseqüências são incertas, ou seja, conforme Wilkinson (1992), são aqueles em que se tem dados suficientes para suspeitar do problema, mas não suficientes para ter certeza, estando as ações direcionadas para reunirem dados que confirmem, transformando em reais ou possíveis, ou eliminem o problema.

Seguindo as mesmas regras para a função assistencial, as declarações diagnósticas na função administrativa também descrevem o problema, as etiologias e as evidências. Com base nos escritos de Wilkinson (1992) e Alfaro-Lefevre (2005), embora inteiramente direcionados para a função assistencial, pode-se afirmar que a maioria dos rótulos diagnósticos administrativos são possuidores de três componentes:

Problema: Também referido como nome ou título. É a descrição concisa do macroproblema. Essa descrição pode ser acompanhada pelo vetor de descrição do problema (VDP).

Etiologia: Descreve as causas (microproblema, nó explicativo ou crítico).

Evidências: Descreve as conseqüências (microproblemas, nó explicativo).

Para Diagnósticos Reais a redação deve ser feita usando os três componentes, adotando a seguinte regra: Problema relacionado à 
(r/à) Etiologia(s) evidenciado por (e/p) Evidência(s). Por exemplo: Déficit quantitativo de recursos humanos relacionado à dimensionamento de Enfermagem inadequado evidenciado por existência de um enfermeiro para unidade com oitenta pacientes internados.

Os Diagnósticos Potenciais podem ser redigidos usando dois componentes, seguindo a regra: Problema relacionado à (r/à) Etiologia(s). Como por exemplo: Risco para higienização da unidade prejudicada r/à carência de materiais de limpeza.

Para redigir rótulos para Diagnósticos Possíveis, simplesmente podemos utilizar somente o primeiro componente (problema), nomeando o possível problema. Por exemplo: Possível insatisfação da equipe de Enfermagem com implantação de nova rotina de trabalho.

Propõe-se a utilização de um formulário próprio para registrar os diagnósticos de Enfermagem (Figura 22). 


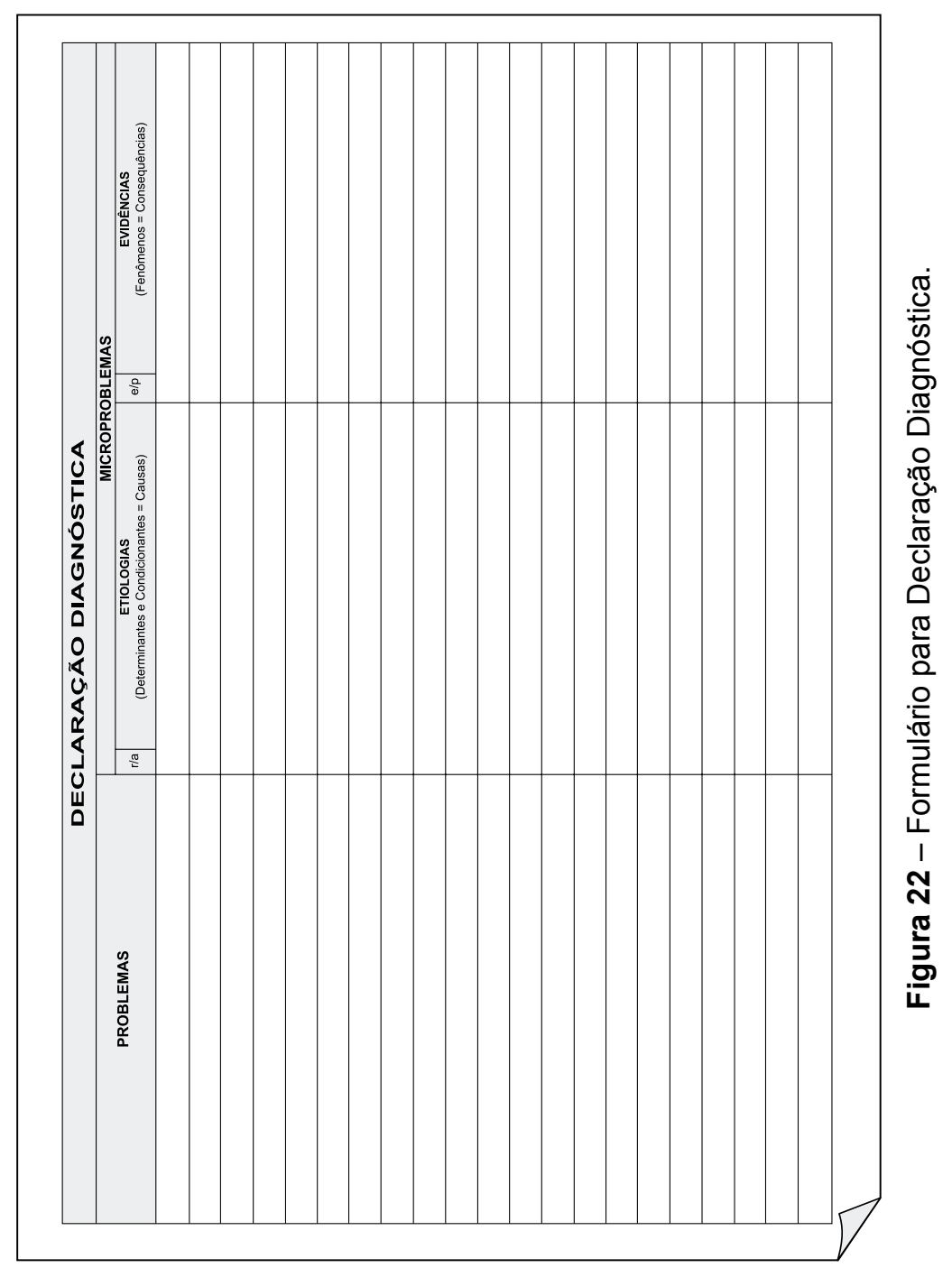




\section{2 \\ Momento de planejamento}

Em relação ao PES, esse momento do processo de Planejamento em Enfermagem corresponde aos momentos Normativo (priorização, objetivos e estratégias de ação) e Estratégico (análise de viabilidade, estratégias viabilizadoras e nível de solução do problema).

Suas atividades são iniciadas com o estabelecimento de prioridades para as intervenções, passando pela definição dos objetivos, pela prescrição das ações a serem executadas para o alcance dos objetivos (estratégia de ação), finalizando com a análise de viabilidade e elaboração do plano de ação.

O plano de ação, contendo as atividades interventoras para prevenirem, minimizarem ou corrigirem os problemas explicados e diagnosticados nos momentos anteriores, representa o produto final desse momento.

\subsection{Priorização das intervenções}

Existem vários métodos que podem ser adotados para a priorização das intervenções, devendo estes ser definidos, em consenso, pelos atores sociais.

No PES pode-se priorizar as intervenções através dos nós críticos detectados, priorizando aqueles que, ao serem transformados em metas/objetivos alcançados, de forma decrescente, promove alteração de um número maior de causas. 
Para o ZOPP e o MAPP, além dos nós críticos, pode-se estabelecer como critério de priorização a hierarquia de causa-efeito construída na árvore de problemas, gerando uma hierarquia de objetivos. Ou seja, as causas terminais devem ser priorizadas porque pode-se esperar um impacto em cadeia na resolução dos restantes microproblemas (PENA, 2004).

\subsection{Definição dos objetivos}

Vimos que um problema deve ser formulado na negativa, expressando negativamente a situação, tendo a árvore de problemas e o fluxograma situacional como técnicas para a sua explicação e representação gráfica. Estreitamente relacionado a isso, está a formulação dos objetivos, que trata do estabelecimento da situação futura desejada para se reduzir ou eliminar os problemas atuais, e representa a expressão positiva da formulação do problema, tendo como técnicas para elaboração e representação gráfica a árvore de objetivos (no ZOPP e no MAPP) (Figura 23) e a Rede de Resultados ou Árvore de Apostas (no PES).

A definição dos objetivos está fundamentada, principalmente, nas etapas metodológicas do Enfoque Estratégico da Programação em Saúde (Escola de Medellin), que prevê a formulação de uma imagem-objetivo através da comparação desta com a situação inicial. Ou seja, a imagem-objetivo representa situação oposta (situação objetiva - futura) da situação problema (inicial presente). Além disso, do mesmo modo que os problemas, com seus critérios e regras, os objetivos são formulados de forma clara e prática, contendo: o que, quem, onde e quando. 


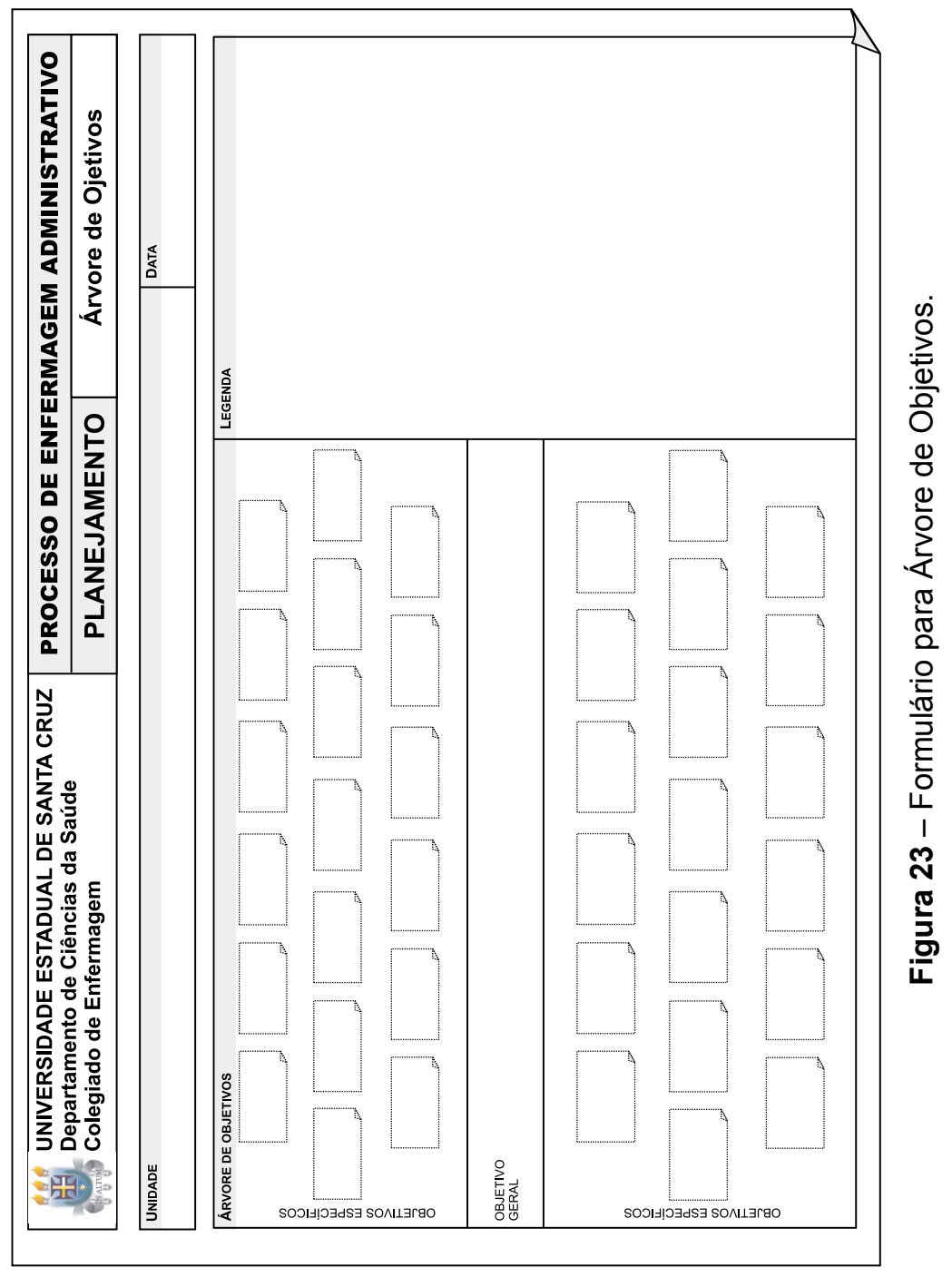


Por exemplo: se o problema analisado é "excesso" de absenteísmo do pessoal de nível médio da equipe de Enfermagem da enfermaria cirúrgica no ano de " 2005 ", o objetivo é "redução" de absenteísmo do pessoal de nível médio da equipe de Enfermagem da enfermaria cirúrgica no ano de "2006".

Seguindo essa orientação, são definidos o objetivo geral e os específicos. Dessa forma, o objetivo geral é a expressão positiva da formulação do macroproblema (problema central) e os objetivos específicos expressam positivamente os microproblemas (causas e conseqüências). Por exemplo:

\begin{tabular}{l|l}
\hline $\begin{array}{l}\text { Diagnóstico de } \\
\text { Enfermagem }\end{array}$ & $\begin{array}{l}\text { Excesso de absenteísmo do pessoal de } \\
\text { nível médio da equipe de Enfermagem da } \\
\text { enfermaria cirúrgica no ano de 2005 r/à } \\
\text { sobrecarga de trabalho. }\end{array}$ \\
\hline Macroproblema & $\begin{array}{l}\text { Excesso de absenteísmo do pessoal de } \\
\text { nível médio da equipe de Enfermagem da } \\
\text { enfermaria cirúrgica no ano de 2005. }\end{array}$ \\
\hline Objetivo Geral & $\begin{array}{l}\text { Redução de absenteísmo do pessoal de } \\
\text { nível médio da equipe de Enfermagem da } \\
\text { enfermaria cirúrgica no ano de 2006. }\end{array}$ \\
\hline Microproblema & Sobrecarga de trabalho. \\
\hline Objetivo & $\begin{array}{l}\text { Carga de trabalho dentro dos padrões } \\
\text { aceitáveis }\end{array}$ \\
\hline
\end{tabular}

Como já foi dito, a árvore de objetivos e a rede de resultados são as representações gráficas das relações de resolubilidade entre os objetivos, ou seja, representações gráficas dos impactos de determinados objetivos na resolução de outros objetivos. São a rede e a árvore da situação desejada, construídas como uma rede e uma árvore espelho, simétricas, do fluxograma situacional e da 
árvore dos problemas, transformando os microproblemas priorizados em objetivos específicos, e a expressão positiva do problema central em objetivo geral.

Para construir a rede de resultados ou a árvore de objetivos basta reescrever cada um dos problemas, elencados no fluxograma situacional ou na árvore de problemas, na forma positiva futura. Dessa forma, obtém-se uma rede ou uma árvore simétrica ao fluxograma situacional ou à árvore de problemas.

\subsection{Prescrição de intervenções (ações)}

Após a definição dos objetivos, são identificadas as ações necessárias para o seu alcance. Essas ações são, concordando com Oliveira (1998), definidas como um caminho, ou maneira, estabelecido e adequado para alcançar os objetivos previamente traçados. Complementando essa definição, Gandin (2000) informa ser uma proposta para diminuir a distância entre a realidade encontrada e a realidade desejada.

No processo de Planejamento em Enfermagem, as ações podem ser denominadas como estratégias de ação, intervençōes, ou prescrição. $\mathrm{O}$ desenho das estratégias de ação é um processo criativo e comunicativo, em que as ações prescritivas são realizadas de forma coletiva, ou seja, por todos os atores sociais (TEIXEIRA, 2001), e não individualmente, como tradicionalmente (principalmente na clínica) ocorre na Enfermagem. O papel do enfermeiro é, então, modificado para a liderança, mediação e coordenação do processo de planejamento.

Para cada objetivo específico, deve-se traçar as açōes necessárias para o alcance dos objetivos, ou seja, é delineada uma ou mais estratégias para cada objetivo específico, e transcritas para a coluna "Prescrição - estratégias de ação" do formulário denominado "Estratégias" (Figura 24). As estratégias deverão ser redigidas de forma sintética e utilizando verbos que expressem uma proposta de intervenção (ARTMANN, 2000). 


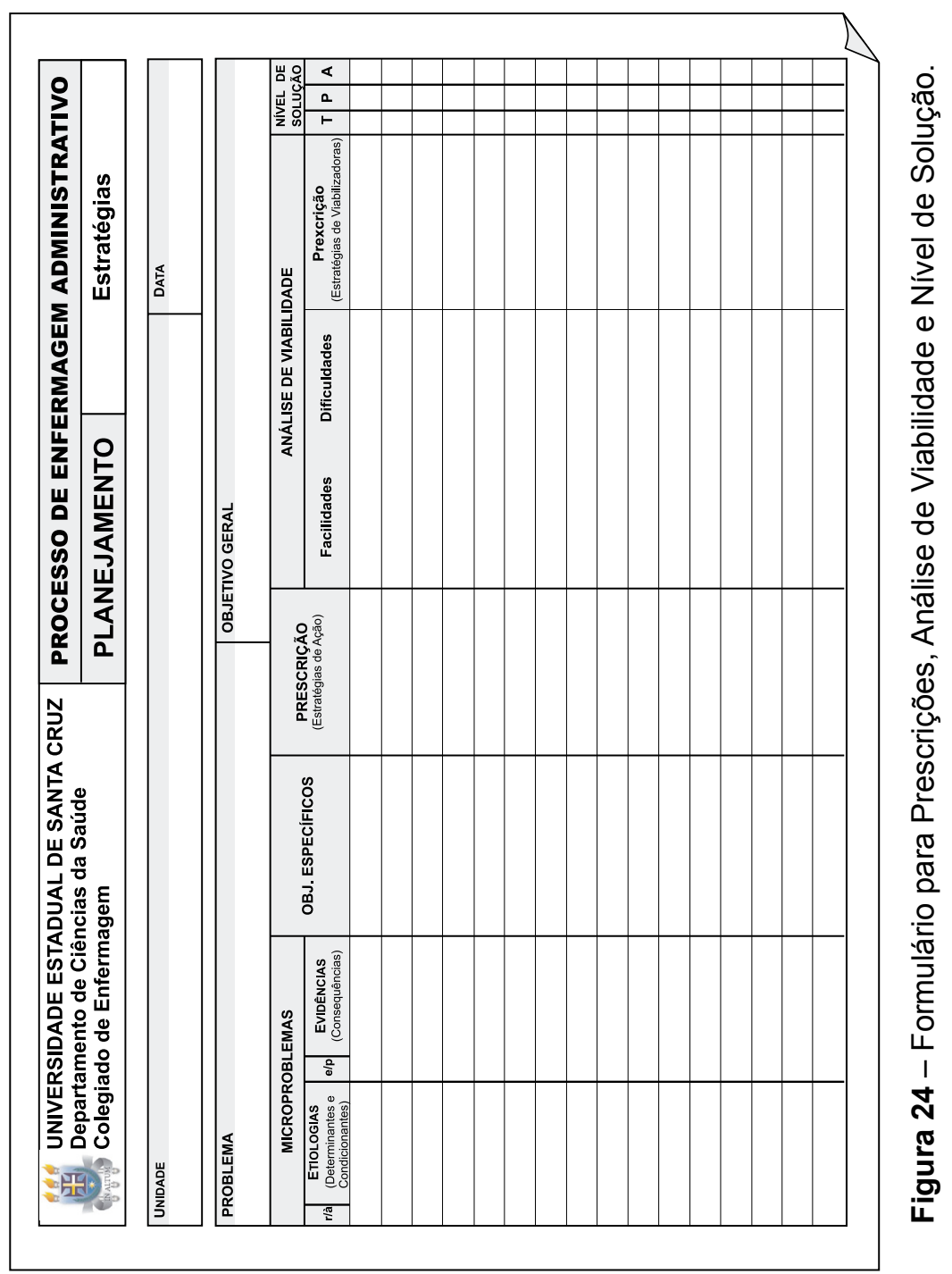




\subsection{Análise de viabilidade}

Trata-se de verificar se as ações (prescrições/estratégias de ação) têm viabilidade. É feita ao estabelecer a relação entre os recursos necessários e os recursos existentes efetivamente. Parte-se do princípio de que não adianta um plano bem elaborado se não existem os recursos para pô-lo em prática. Assim, se uma ação elimina os principais problemas, mas não se tem os recursos necessários para realizá-la, então há necessidade de construir a viabilidade das ações, para aumentar o número de recursos que o ator controla e terem mais eficácia as suas açôes (SILVA, 2001).

No processo de Planejamento em Enfermagem, é possível fazer uma análise simplificada de viabilidade (Figura 24), ao identificar as facilidades e as dificuldades para a operacionalização das açôes propostas. Nessa análise, verifica-se a disponibilidade ou não de recursos de toda natureza: recursos de poder, humanos, materiais, financeiros, de conhecimento, de tempo etc. (VILASBOAS; TEIXEIRA, 1999).

Após identificar as facilidades e as dificuldades, devem ser definidas as estratégias viabilizadoras, ou seja, as ações necessárias para aumentar as facilidades e superar as dificuldades, buscando as estratégias que, sendo executadas antes ou paralelamente, permitam ou favoreçam a execução das estratégias de ação.

Complementando a análise de viabilidade, é identificado o nível de solução. Esta atividade consiste em identificar o grau de governabilidade do ator principal, ou, a depender da situação, do grupo de atores diretamente envolvidos na operacionalização das açôes, através da identificação da acumulação e da desacumulação de poder. É preciso reconhecer os três tipos de poder postulados pelo Pensamento Estratégico, de Mario Testa (TESTA, 1992): o Técnico (T), o Político (P) e o Administrativo (A) (Figura 24). 
O nível de solução aponta as intervenções diretas, aquelas ações que estão no espaço de alta governabilidade do(s) ator(es), e as intervenções de demandas, que são as ações necessárias para alcançar a situação-objetiva, no entanto, estão com baixa governabilidade ou fora do seu espaço de atuação. Nesse último caso, busca-se uma maior viabilidade através da ampliação da governabilidade, através da busca de adesôes, onde a capacidade de negociação e a ampliação dos processos comunicativos tornam-se fundamentais (ARTMANN, 2000).

\subsection{Plano de ação}

Cada estratégia, seja ela de ação ou viabilizadora, será desdobrada em atividades, que expressem detalhadamente o seu conteúdo, os responsáveis e os prazos para alcançar os objetivos propostos, constituindo, assim o Plano de Ação (Figura 25). 


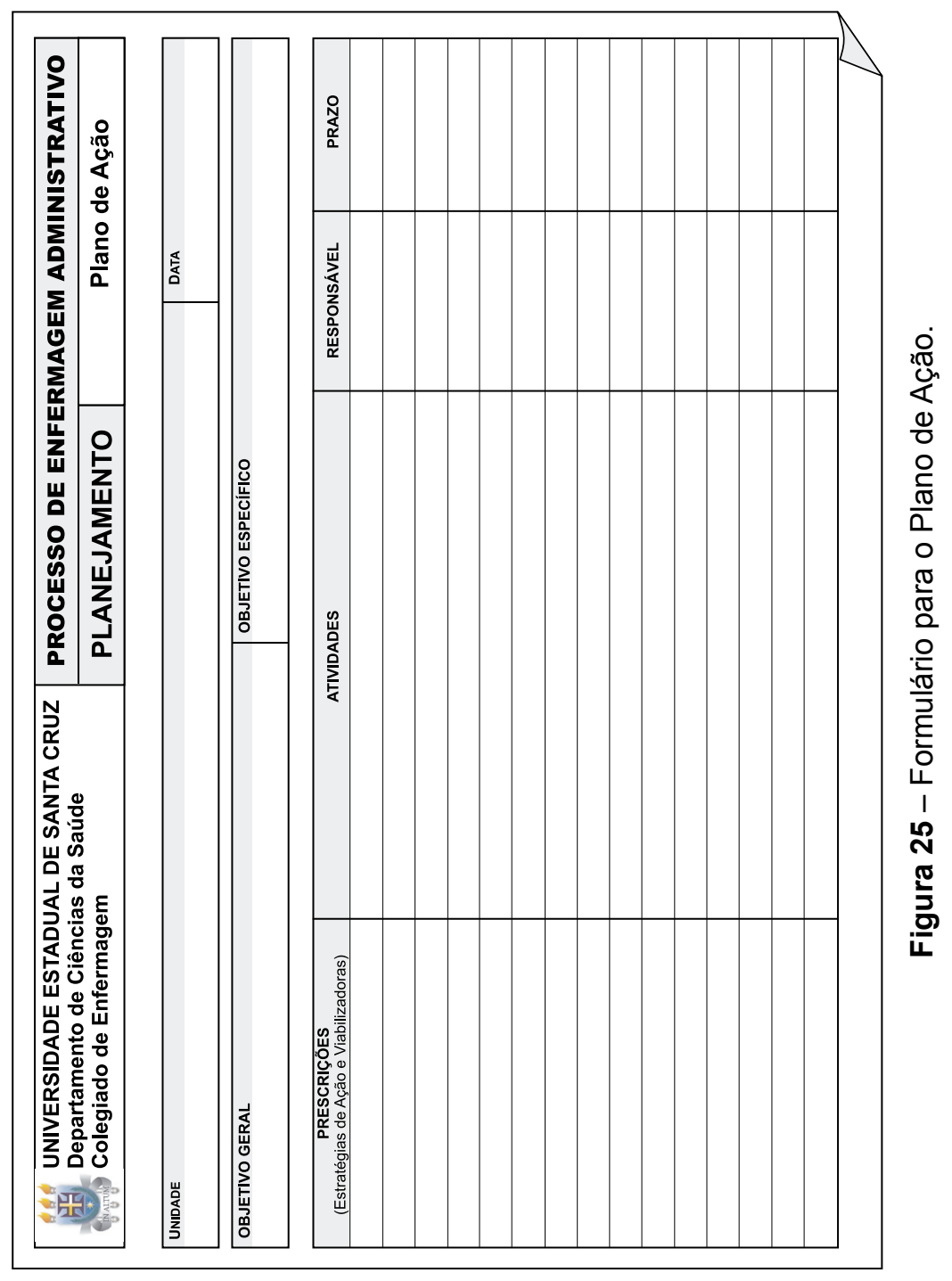


É desenhado um plano de ação para cada objetivo específico, contendo as atividades necessárias para operacionalizar as estratégias. Enquanto as estratégias expressam como os objetivos podem ser alcançados, as atividades representam todas as ações que indicam como será realizada a estratégia.

Conforme Tancredi et al. (1998), no plano de ação, é necessário designar, para as intervençôes diretas, um responsável pela execução de cada atividade e prestação de contas junto ao ator que lidera a intervenção. No caso das intervenções de demanda, é designado um responsável pela monitoração da atuação do ator que tem a governabilidade. Silva (2001) reforça que esse responsável nem sempre terá que realizar a ação, mas será fundamental para que essa ação seja cumprida, tendo nome e sobrenome, não podendo ser o grupo todo.

Silva (2001) chama atenção para a importância do plano de ação ao assegurar que ele é fruto do planejamento. Vários planejamentos fazem apenas essa última parte e, depois, as pessoas se cobram por não conseguirem chegar aos resultados. Reconhece-se que planejar requer visão ampla, criatividade e propostas viáveis, daí se questionar: Quem não explicou a realidade, não avaliou possibilidades, que chances de êxito terá na hora da ação?

Para saber se as ações são necessárias e suficientes a fim de alcançar o resultado esperado, esse autor sugere fazer a seguinte pergunta: o que precisamos fazer, para chegar a este resultado? 


\section{3 \\ Momento de implementação}

Em relação ao PES, esse momento do processo de Planejamento em Enfermagem corresponde ao momento Tático-operacional. Sua atividade principal concentra-se na execução do plano de ação. É um momento decisivo do planejamento situacional, considerado o mais importante do ponto de vista do impacto porque é onde tudo se decide. Não se pode esquecer que o planejamento estratégico só termina quando é executado, se opondo à visão tradicional do "plano-livro" que, separando planejadores dos executores, estabelece uma dicotomia insuperável entre o conhecer e o agir (TONI, 2006).

Por ser um plano flexível e adaptável à conjuntura, durante a sua operacionalização, os atores responsáveis continuam a investigação com a permanente coleta de dados, que subsidiam a avaliação do plano e a retroalimentação do sistema para o ajuste ou replanejamento das ações.

É imprescindível o papel do enfermeiro enquanto gerente do plano, monitorando a realização das ações, e, ao mesmo tempo, buscando suprir as necessidades de cada ator para realizar suas açôes. Com a incorporação dos novos desafios surgidos no dia-a-dia da execução do plano, considera-se que a realidade é dinâmica e outros atores estão "jogando", também, contra ou a favor do plano (SILVA, 2001). 


\section{4 \\ Momento de avaliação}

Embora a Avaliação seja apontada como último momento do Processo de Enfermagem, está presente em todos os outros momentos do processo. Em relação ao PES, esse momento de Planejamento em Enfermagem também corresponde ao momento Tático-operacional. Sua atividade principal concentra-se na avaliação dos resultados do impacto nos problemas selecionados, que se traduzem em novas situaçôes mais favoráveis do que a situação inicial.

Através do acompanhamento contínuo diante das modificações na conjuntura local, estadual e nacional e das próprias modificações na realidade decorrentes da execução das ações (VILASBOAS; TEIXEIRA, 1999), são avaliados os desvios encontrados, são realizados os ajustes por meio da adoção de medidas corretivas, representadas por ações que são incorporadas ao plano original e devidamente monitoradas.

Para o acompanhamento da execução do plano de ação, gerado pelo processo de Planejamento em Enfermagem, sugere-se a metodologia empregada na PPLS (VILASBOAS; TEIXEIRA, 1999), com a utilização de indicadores para medir o grau de cumprimento das açóes necessárias para atingir os objetivos específicos (Figura 26). 


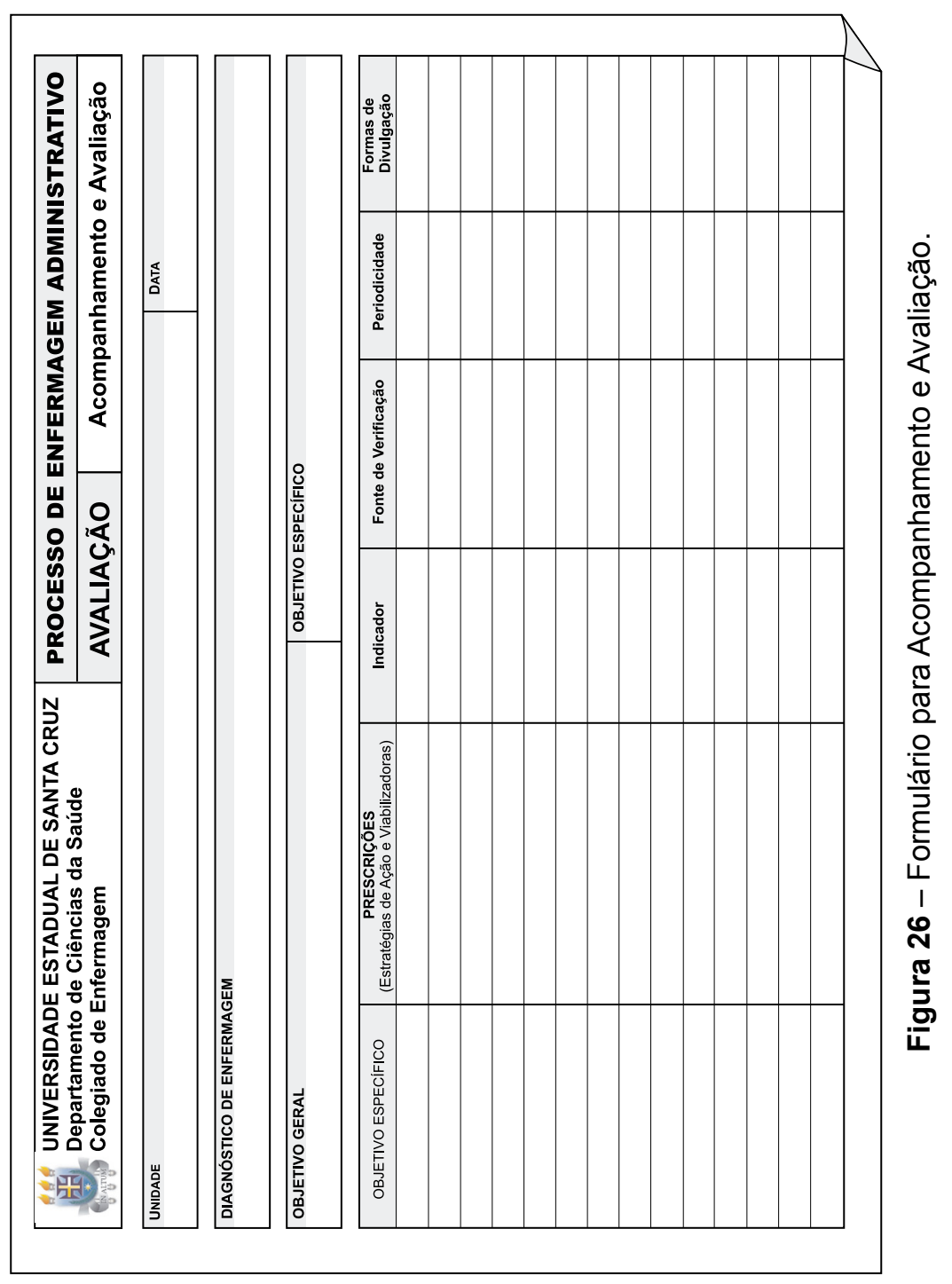




\section{REFERÊNCIAS}

ALFARO-LEFEVRE, R. Aplicação do Processo de Enfermagem: promoção do cuidado colaborativo. 5 ed. Porto Alegre: Artmed, 2005.

ARIOLI, E. E. Análise e Solução de Problemas - O método da Qualidade Total com Dinâmica de Grupo. Rio de Janeiro: Qualitymark, 1998.

ARNDT, C.; HUCKABAY, L. M. D. Administração em Enfermagem. Trad. de Maria Stella Teixeira de Oliveira e Clenir Bastos Marra Pereira. Rio de Janeiro: Interamericana, 1983.

ARTMANN, E. O Planejamento Estratégico Situacional no Nível Local: um instrumento a favor da visão multissetorial. In: Centro de Tecnologia, Trabalho e Cidadania - Oficina Social. Desenvolvimento local (Cadernos da Oficina Social 3). Rio de Janeiro: Oficina Social, 2000 .

ATKINSON, L. D.; MURRAY, M. E. O Processo de Enfermagem e o Planejamento da Assistência ao Paciente. In: Fundamentos de Enfermagem: introdução ao Processo de Enfermagem. Rio de Janeiro: Guanabara Koogan, 1989. p. 215-231.

AZEVEDO, C. da S. Planejamento e Gerência no enfoque estratégico-situacional de Carlos Matus. Cad. de Saúde Pública, Rio de Janeiro: v. 8, n. 2, p. 129-133, 1992.

BARBOSA, N. B. Estudo de um caso de implantação de projeto de redução da mortalidade infantil e seu papel. 2000. 129 f. Dissertação (Mestrado em Medicina Social) Instituto de Medicina Social - IMS. Universidade Estadual do Rio de Janeiro, Rio de Janeiro 2000. 129p. Disponível em: <http://www.opas.org.br/servico/arquivos/Sala5513.pdf\#search=\%22\%20\%22M\%C3\%A9todo\%20Altadir\%22\%22> Acesso em: abr. 2006.

BARELli, W.; TROYANO, A. A. Planejar como Arte de Governo. Em Perspectiva, São Paulo: v. 4, n. 5, p. 18-22, 1991. 
BASTO, H. R. Project Cycle Managment - Ciclo do Projecto. Lisboa, Portugal. IMVF - Instituto Marquês de Valle Flôr, Junho de 2004. (Ficha Formativa No 6). Disponível em: <http://www.plataformaongd.pt/site2/publique/media/ Ficha\%206_Ciclo\%20do\%20 Projecto.pdf> Acesso em: nov. 2004.

BRASIL, Ministério da Saúde. Fundação Nacional de Saúde. Desenvolvimento Gerencial de Unidades Básicas do Distrito Sanitário - Projeto GERUS. Brasília: Fundação Nacional de Saúde, 1995.

BURSZTYN, I.; RIBEIRO, J. M. Avaliação participativa em programas de saúde: um modelo para o programa de saúde do adolescente. Cad. de Saúde Pública, Rio de Janeiro: v. 21, n. 2, p. 404-416, mar./ abr. 2005.

CASTILHO, V.; GAIDZINSKI; R. R. Planejamento da assistência de Enfermagem. In: KURCGANT, P. (Org.). Administração em Enfermagem. São Paulo: EPU, 1991. p. 207-214.

CHIAVENATO, I. Administração: teoria, processo e prática. São Paulo: McGraw-Hill do Brasil, 1985.

Administração nos novos tempos. 2 ed. Rio de Janeiro: Campus, 1999. . Introdução à Teoria Geral da Administração. 6 ed. Rio de Janeiro: Campus, 2000.

CIAMPONE, M. H. T. Metodologia do planejamento na Enfermagem. In: KURCGANT, P. (Org.). Administração em Enfermagem. São Paulo: EPU, 1991. p. 41-58.

CORDIOLLI, Sérgio. Enfoque Participativo do Trabalho com grupos. In: Markus Brose (Org.) Metodologia participativa. Uma Introdução a 29 instrumentos. Porto Alegre: Tomo Editorial, 2001. p. $25-40$.

CURY, A. Organização e métodos: uma visão holística. 8 ed. São Paulo: Atlas, 2005.

DANIEL, L. F. A Enfermagem planejada. 3 ed. São Paulo: EPU, 1981. 
DANIEL, L. F. Enfermagem: modelos e processos de trabalho. São Paulo: EPU, 1987.

DE MASI, D. O ócio criativo. Rio de Janeiro: Sextante, 2000.

FRACOLLI, L.A.; EGRY, E.Y. Processo de trabalho em gerência: instrumento potente para operar mudanças nas práticas de saúde? Ver. Latino-am. Enfermagem, Ribeirão Preto, Ano 9, n. 5, p. 13-18, set./out. 2001.

GANDIN, D. A prática do planejamento participativo: na educação e em outras instituições, grupos e movimentos dos campos cultural, social, político, religioso e governamental. 8 ed. Petrópolis, RJ: Vozes, 1994.

GERGES. M. C.; ERDMANN, A. L. Planejamento estratégico como um instrumento da gestão estratégica para a Enfermagem. Texto e Contexto Enf., Florianópolis: v. 4, n. 1, p. 180-190, 1995.

HELMING, S.; GÖBEL, M. Planejamento de projetos orientado por objetivos (ZOPP): um guia de orientação para o planejamento de projetos novos e em andamento. Frankfurt: Deutsche Gesellschaft für Technische Zusammenarbeit (GTZ) GmbH, Multiprint, 1998.

HORTA, W de A. Processo de Enfermagem. São Paulo: EPU, 1979.

HUERTAS, F. O método PES: entrevista com Matus. Trad. Giselda Barroso Sauveur. São Paulo: FUNDAP, 1996.

KAST, F. E.; ROSENZWEIG, J. E. Organização e administração: um enfoque sistêmico. 2 ed. São Paulo: Pioneira, 1980.

KURCGANT, P. As teorias de administração e os serviços de Enfermagem. In: KURCGANT, P. (Org.). Administração em Enfermagem. São Paulo: EPU, 1991. Cap. 1, p. 3-13.

KWASNICKA, E. L. Teoria Geral da Administração: uma síntese. 2 ed. São Paulo: Atlas, 1989. Cap. 9, p. 139-146. Abordagem contingencial.

LANA, F. C. F.; GOMES, E. L. R. Reflexões sobre o planejamento em saúde e o processo de reforma sanitária brasileira. Revista Latino-americana de Enfermagem, Ribeirão Preto: EERPUSP. 1. p. 97110, jan. 1996. 
LINS, I. C. P.; ANJOS, M. O. dos; OLIVEIRA, N. S.; MATOS-SANTANA, R. Integração das teorias Burocrática, dos Sistemas e Contingencial na Administração dos Serviços de Enfermagem. In: Livro Resumo/ 16 Encontro de Enfermagem: produzindo e pesquisando o cuidado de Enfermagem - a realidade do Nordeste. Salvador: ABEn - Seção Bahia, 2000. p. 54-54.

MARQUIS, B. L.; HUSTON, C. J. Administração e liderança em Enfermagem: teoria e aplicação. 2 ed. Porto Alegre: Artes Médicas Sul, 1999.

MASSAROLLO, M. C. K. B. Estrutura Organizacional e os Serviços de Enfermagem. In: KURCGANT,P. (Org.). Administração em Enfermagem. São Paulo: EPU, 1991. Cap. 3. p. 23-39.

MATOS-SANTANA, R. Planejamento estratégico no gerenciamento clínico de Enfermagem. 2001. 172 f. Dissertação (Mestrado em Enfermagem) - Escola de Enfermagem, Universidade Federal da Bahia/Universidade Estadual da Santa Cruz. Salvador, 2001.

MATTOS, R. A. O Processo de construção conceitual do método CENDES-OPS. Rio de Janeiro: UERJ/MS, 1993.

MATUS, C. Política, planejamento e governo. 2 v. Brasília: IPEA, 1993.

MAXIMIANO, A. C. A. Teoria Geral da Administração: da escola científica à competitividade na economia globalizada. 2 ed. São Paulo: Atlas, 2000.

MERHY, E. E. Planejamento como tecnologia de gestão: tendências e debates do planejamento em saúde no Brasil. In: GALLO, E (Org.). Razão e planejamento: reflexões sobre Política, Estratégia e Liberdade. São Paulo: Hucitec/Abrasco. 1995. p. 117-149.

MOTTA, P. R. Gestão contemporânea: a ciência e a arte de ser dirigente. 9 ed. Rio de Janeiro: Record, 1998. Cap. 4. p. 78-109. Gerenciando o futuro: a conquista da visão estratégica.

OLIVEIRA, D. de P. R. de. Planejamento estratégico: conceitos, metodologia e práticas. 12 ed. São Paulo: Atlas, 1998. 
PAIM, J. S. O movimento pelo Planejamento de Saúde na América Latina. Revista Baiana de Saúde Pública, Salvador, v. 10, n. 1. p. 45-52, 1983.

PALADINI, E. P. Gestão da Qualidade no Processo: a qualidade na produção de bens e serviços. São Paulo: Atlas, 1995.

PAUL, C.; REEVES, J. S. Visão Geral do Processo de Enfermagem. In: GEORGE, J. B. Teorias de Enfermagem: os fundamentos à prática profissional. 4 ed. Porto Alegre: Artes Médicas Sul, 2000.

PENA, R. (Org.). Metodologia de Planejamento de Projetos por Objetivos: manual do formando. Porto, Portugal: Bee-Consulting, 2004. Disponível em: <http:/www.arvoredeproblemas.com/nm_quemsomos.php?id=6> Acesso em: dez. 2005.

ROSSI, L. A.; CASAGRANDE, L. D. R. Processo de Enfermagem: a ideologia da rotina e a utopia do cuidado individualizado. In: CIANCIARULLO, T. I.; GUALDA, D. M. R.; MELLEIRO, M. M.; ANABUKI, M. H. Sistema de Assistência de Enfermagem: evolução e tendências. São Paulo: Ícone, 2001.p. 41-62.

SÁ, M. de C. Planejamento estratégico em saúde: problemas conceituais e metodológicos. Rio de Janeiro: 1993. 425p. Dissertação (Mestrado) - Escola Nacional de Saúde Pública, Fundação Osvaldo Cruz.

SÁ, M.; ARTMANN, E. Planejamento estratégico em Saúde: desafios e perspectivas para o nível local. ln: MENDES (Org.). Planejamento e programaçáo local da Vigilância da Saúde. OPS, Série Desenvolvimento de Serviços de Saúde. n. 13, 1994, p. 19-44.

SANTOS, K. S.; MOURA, D. G. de. Um estudo de caso aplicando a técnica de grupo focal para análise e melhoria de serviço público de emergência odontológica na região de Belo Horizonte. Educ. Tecnol., Belo Horizonte, v. 5, n.2, p.43-46, jul./dez. 2000

SCHRAIBER, L. B. Programação local hoje: a força do debate. In: SCHRAIBER, L. B. (Org.). Programação em saúde hoje. 2 ed. São Paulo: Hucitec, 1993. Introdução. p. 11-35. 
SILVA. A. G. I. da. Gerenciamento clínico em Enfermagem e qualidade da assistência. Nursing. São Paulo, n. 20. p. 12-15, 2000.

SILVA, R. M. da. Teoria organizacional do Planejamento Estratégico Situacional e a gestáo no setor saúde: uma análise da experiência da Santa Casa de Misericórdia do Pará. Rio de Janeiro: 1994. 140p. Dissertação (Mestrado) Escola Nacional de Saúde Pública, Fundação Osvaldo Cruz.

SILVA, M. J. P. Onze passos do planejamento estratégico participativo. In: Markus Brose (Org.) Metodologia participativa: uma introdução a 20 instrumentos. Porto Alegre: Tomo Editorial, 2001. p.161-176.

SMELTZER, S. C.; BARE, B. G. O Processo de Enfermagem. In: Brunner e Suddarth: tratado de Enfermagem médico-cirúrgica. 7 ed. Rio de Janeiro: Guanabara Koogan, 1993. p. 29-35.

SPAGNOL,C.A. (Re)pensando a gerência em Enfermagem a partir de conceitos utilizados no campo da Saúde Coletiva. Ciência \& Saúde Coletiva, Ano 10, n. 1. p.119-127, 2005.

TANAKA, O. Y.; MELO, C. Avaliação de Programas de Saúde do Adolescente - um modo de fazer. São Paulo: Edusp, 2001.

TANCREDI, F. B.; BARRIOS, S. R. L.; FERREIRA, J. H. G. Planejamento em saúde. São Paulo: Faculdade de Saúde Publicada Universidade de São Paulo, 1998. (Série Saúde \& Cidadania).

TEIXEIRA, C.F. Planejamento Municipal em Saúde. Salvador: Universidade Federal da Bahia, Instituto de Saúde Coletiva, 2001. . Planejamento e programação situacional em distritos sanitários. In: MENDES, E.V. Distrito Sanitário: o processo social de mudança das práticas sanitárias do Sistema Único de Saúde. São Paulo/Rio de Janeiro: HUCITEC/ABRASCO, 1993. p. 237-265. 
TESTA, M. Mario Testa e o Pensamento Estratégico em Saúde. In: RIVERA, F. J. U. (Org.). Planejamento e programação em saúde: um enfoque estratégico. Trad. de Elizabeth Artmann. 2 ed. São Paulo: Cortez, 1992. p. 57-104.

. Pensamento estratégico e lógica de programação: o caso da saúde. Trad. de Ângela Maria Tijiwa. São Paulo - Rio de Janeiro: Hucitec - Abrasco, 1995.

TONI, J. de. O que é o Planejamento Estratégico Situacional? Revista Espaço Acadêmico, n. 32, jan. 2004. Disponível em: <http://www. espacoacademico. com.br/032/32ctoni.htm> Acesso em: 10 abr. 2006.

URIBE RIVERA, F. J. (Org.). Planejamento e programação em saúde: um enfoque estratégico. Trad. de Elizabeth Artmann. 2 ed. São Paulo: Cortez, 1992.

Planejamento Estratégico Situacional ou Controle de Qualidade Total em saúde? Um contraponto teórico-metodológico. Cadernos FUNDAP, São Paulo: n. 19, p. 25-46, jan./abr.1996.

VILASBOAS, A.L.; TEIXEIRA, C.F. Orientações metodológicas para o planejamento e programação das açôes de vigilância da saúde nas áreas de abrangências do PACS/ Bahia. Quarta versão. ISC-UFBA, Salvador, 1999 (Mimeo).

WILKINSON, J. M. Nursing Process in Action: a critical thinking approach. Califórnia: Addison-Wesley Nursing, 1992. 


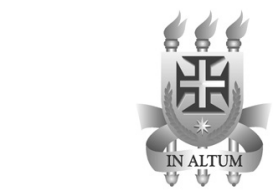

IMPRENSA UNIVERSITÁRIA

Coordenaçāo Gráfica: Luiz Henrique Farias

Designer Gráfico: Cristovaldo C. da Silva

IMPRESSÃo: Davi Macêdo e André Andrade

FotOMECÂNICA: Antônio Vitor

Acabamento: Nivaldo Lisboa

Impresso na gráfica da Universidade Estadual de Santa CruZ - Ilhéus-BA 